\title{
Onshore and offshore evidences for four abrupt "warming" episodes during MIS 6 at the westernmost tip of continental Europe: did they control the migrations of Neanderthals?
}

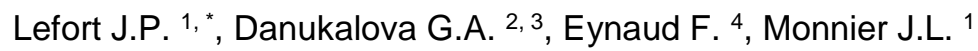

${ }^{1}$ CNRS UMR 6566 CReAAH, Université de Rennes 1, Campus de Beaulieu, Laboratoire

Archéosciences (bât. 24-25), CS 74205, 35042, Rennes Cedex, France

2 Institute of Geology, Ufimian Federal Research Centre, Russian Academy of Sciences, 450077, Ufa,

K. Marx, Str. 16/2, Russia

${ }^{3}$ Kazan Federal University, 18, Kremlevskaya St., 420008, Kazan, Russia

${ }^{4}$ UMR 5805 EPOC, Université de Bordeaux, Allée Goeffroy Saint-Hilaire, F-33615, Pessac, France

* Corresponding author : J.P. Lefort, email address : i.p.lefort@univ-rennes1.fr

danukalova@ufaras.ru ; f.eynaud@epoc.u-bordeaux1.fr ; j.l.monnier@univ-rennes1.fr

\begin{abstract}
:
The total shell production typical of the Pupilla association in the onshore site of Nantois (Brittany, France) evidenced for the first time four brief, abrupt, warm and humid episodes during the Upper Saalian (MIS 6) loess deposition. These "warming" events were also found in the marine deposits of the Celtic Sea (MD032692 core). Comparison with the variations of the sea-level, show that the "warming" episodes were not only of regional interest but corresponded to global events ruled by precession and insolation cycles. Other comparisons with biomarker records (molluscs, charcoal and rodents) of the Paris Basin (VilliersAdam) and Jersey Island (La Cotte de Saint Brolade) confirm the existence of these warmer events. Tentative correlations with the discontinuous Neanderthal dwelling phases recorded in Brittany suggest that these populations were mainly (only?) present in Westernmost Europe during the warmer episodes.
\end{abstract}

Keywords : MIS 6 climatic changes, Westernmost Europe, Malacology, "Warming" episodes, Palaeolithic migrations 
42 During the recent investigations of the loess that make up the Nantois cliff (Northern Brittany

43 - France) located in the eastern part of Saint Brieuc Bay (48 $\left.35^{\prime} 50.57^{\prime \prime N}, 2^{\circ} 31^{\prime} 51.46^{\prime \prime} \mathrm{W}\right)$, (that

44 is to say almost at the westernmost end of continental Europe), we discovered the existence of 45 four short and abrupt Late Saalian (MIS 6) "warmer" episodes. This discovery was based on 46 detailed malacological, physical and geochemical studies (Danukalova et al., 2017). In order 47 to better understand the origin of these unexpected climatic phases, it was decided to compare 48 these events with contemporaneous sites already studied onshore and offshore. These sites 49 were selected because they are located at about the same latitude as Nantois $\left(47^{\circ} \mathrm{N}\right)$ and thus, 50 received the same amount of insolation. They are also all located at about the same distance 51 (450 kilometres) respect with the British ice sheet (Fig. 1).

52 This discovery was also the opportunity to check if the discontinuous middle Palaeolithic 53 dwelling of Neanderthal in Brittany (Monnier, 1973) was a valid hypothesis.

55 Fig. 1 here

\section{The Upper Saalian background in Europe}

The Late Saalian period represents the penultimate glacial episode. At a small scale it was

60 characterized by the huge development of the boreal ice-sheet and especially by its large 61 geographical extension over northeastern Europe. At that time, the Barents-Kara ice-sheet 62 represented one of the largest glacial area (Svendsen et al., 2004; Astakhov et al., 2016). The 63 Late Saalian was contemporaneous with the Moscow glaciation and was encompassing the 64 multi-stepped Termination 2 (Seidenkrantz et al., 1996). The studied area was located at the 65 transition between a cold domain associated with this huge ice-sheet and the warmer North 66 Atlantic realm. All the sites cited in this paper were under the influence of a steep temperature 67 gradient and were, thus, affected by rapid climatic changes. The cold periods were 68 characterized by the deposition of loess in the East and a rapid regression of the sea in the 
West. On the contrary the climatic improvements were responsible for an important melting of the southern border of the boreal ice-sheet in the East and for the formations of onshore incipient soils (and for the southward drift of icebergs) in the West (Lefort et al., 2017).

\section{The Upper Saalian background in the western part of France}

Four well-documented Upper Saalian sites are known in the Western half of France. One is located in the Paris Basin (Villiers-Adam), one in Saint Brieuc Bay (Nantois) and one on Jersey Island (La Cotte de St Brelade). The last site corresponds with a marine borehole drilled in the Celtic Sea (core MD 03-2692). The site of Nantois has been often visited since the first study of Mazeres (1938) but it is only recently that a complete stratigraphical and malacological study of this section has been reappraised (Danukalova et al., 2017).

\subsection{The Nantois site (Brittany)}

It is the place where the stratotype of the Nantois Formation was first defined (Monnier, 1973; Monnier and Bigot, 1987). The Eastern part of this cliff is characterized by the superimposition of two loess formations of Saalian and Weichselian ages. This outcrop is important in the regional geology because it is one of the very few places where the Saalian loess is not completely decalcified. Out of this zone the pre-Eemian sediments are very patchy. The general stratigraphy of the Nantois cliff will not be described here in details, all the information can be found in Monnier (1973) and Loyer et al. (1995). The complete reappraisal of this outcrop has been proposed because the aspect of the cliff, continuously eroded by the sea, was modified since the first stratigraphic description. The main results of this study are summarized below.

- Main characteristics of the Upper Saalian Nantois section:

Section A of figure 2 displays the initial layers numbering proposed by Monnier (1973). In this diagram, the Upper Saalian section is located between layers 26 and 37. Nowadays layers 36 and 37 look thicker and more complex than previously estimated. Section B displays more details, either because some of the layers have been subdivided or because they were not observed before their erosion by the sea. In this diagram, the Upper Saalian is located 
102 between layers 1 and 10. We send back the reader to a recent paper (Danukalova et al., 2017)

103 for more stratigraphical details.

104 The bottom and the top of the Upper Saalian section can be clearly observed on the field 105 (Monnier, 1973). The limit between the Inter-Saalian warming and the Upper Saalian glacial 106 deposits is underlined by poorly rounded fragments of rock associated with remnants of an 107 old soil and a yellowish-grey loess-like loam incorporated in a gravelly "head" formation 108 (Fig. 2A). An alterated "head" associated with a reddish loam marks the contact between the 109 Upper Saalian and the Eemian. Between these two limits a typical calcareous loess was 110 continuously deposited.

111 Quantification of the number of shells was made between layers 2 and 10 (Fig. 2 B). Apart 112 the previous discoveries of Mazeres (1938) and Puissegur (see Monnier, 1973) no systematic 113 mollusc study was undertaken in this area. The sampling of the section was made at $10 \mathrm{~cm}$ 114 intervals following the methodology of Sümegi and Krolopp (2002) but with a closer spacing. 115 The quantity of extracted shells was very different depending on the examined level (Table 116 1). Their abundance is given according to the method of Ložek (1964) and determinations 117 were made following the various sources cited in Danukalova et al. (2013). Because the 118 number of mollusc shells is important in the interpretation of the Upper Pleistocene terrestrial 119 deposits, shells were examined and extracted individually. The number of complete shells 120 plus the number of apices or apertures (considered as equivalent to one shell when taken 121 together) were counted. Additionally, undetermined shell fragments were counted in order to 122 get quantitative environmental information. The percentage of the different species in each 123 sample was not counted, because the method needs more than 200 shell specimens (White et 124 al., 2008) to be valid.

Table 1 here

128 The Nantois malacofauna is usually poor in species, which reflects a cold environment. If the 129 number of shells is given for $2.5 \mathrm{~kg}$ of sediment, a total amount of 397 terrestrial mollusc 130 shells (and 2038 fragments) belonging to 7 species (Succinella oblonga, Pupilla muscorum, 131 Cochlicopa lubrica, Vertigo cf. alpestris, Vallonia pulchella, Hydromiidae, and Limacidae) 132 were identified (Fig. 2). It has been observed that Limacidae (which cannot live in very dry 133 environments) always appear at the same time as the maximum production of shells, which 134 suggests that a wetter and warmer environment was at the origin of their multiplication. 
135 The groups of molluscs were classified according to their modern ecological preferences in 136 temperature, humidity, and vegetation cover following the criteria proposed by Ložek (1964), 137 Likharev and Rammelmeier (1952) and Puisségur (1976). After the analysis of the different 138 species, five mollusc zones were recognized. Basically, the general environment was very 139 cold even if the installation of the permafrost was very late (Van Vliet-Lanoë in Monnier et 140 al., 1997). Malacozones 1b, 3 and 5 correspond with limited "meadows" or littoral dunes 141 associated with a tundra-like open habitat with a grassy vegetation. During these episodes the 142 production of shells was very low which suggests a rather dry and cold environment. 143 Malacozones 1a, 2 and 4 correspond with wet "meadows" probably associated with bushes 144 and trees. During these periods of milder climatic conditions the production of shells was 145 increasing. In total, severe environmental conditions, which did not favoured the biotic 146 production, alternated with improved climatic episodes that generated larger populations of 147 gastropods.

149 Fig. 2 here

151 Although the decalcification of the upper part of the section does not permit to give any 152 malacological information on the climate existing at that time, the presence of "limon à 153 doublets" (LAD, Fig. 2) provides interesting information. The "limon à doublets" (Lautridou, 154 1985) which consists of a thin alternation of sandy and silty loess (often rich in illite and 155 hornblende) with iron-coated silt grains, can be considered as a low-energy overland flow, 156 which developed during one, or successive seasonal snow melts. This facies corresponds to 157 the product of freezing and thawing (Derbyshire et al., 1988). The variability in the anisotropy 158 of the "limon à doublets" facies has been assessed elsewhere by image analysis of scanning 159 electron microscopy (SEM) and optical microscopy. This strong anisotropy has been 160 measured in thin section imagery of loess from Normandy and Poland and is considered as 161 the product of freezing and thawing. This was confirmed by scanning electron microscopy 162 and by experimental freezing of different silts.

163 The zone of "limon à doublet" (or stripped loam) located below layer 26 has been considered 164 (Monnier et al., 1997) as dating from $140 \mathrm{ka}$ and would be equivalent to the Zeifen-Linexert 165 Interstadial (Seidenkrantz et al., 1996). It corresponded to an "early" phase of "boreal" 166 pedogenesis. After the development of this "soil", a short cooling phase degraded the 167 vegetation and it is only after this period that the stability of the Eemian was reached (Van 168 Vliet-Lanoë and Guillocheau, 1995). Taken as a whole, four sedimentary zones witnessing 
169 slightly milder climatic conditions have been recognized during this sever tundra climatic 170 episode.

171 It must be also observed that the largest shell developments are often superimposed onto 172 darkest zones on the field (Fig. 2). These zones correspond to incipient soils, very poor in 173 total organic matter (TOC). Pilot measurements made in these zones and on the "limon à 174 doublet" zone (Dergacheva written communication and work in progress) show that their total 175 organic carbon is ranging between 0.07 and $0.25 \%$ of the total weight. Despite this very low 176 TOC content some darker zones still evidence a very weak magnetic susceptibility 177 (Dergacheva written communication). Those incipient soils cannot be compared with the well 178 developed soils of Eemian age but confirm the existence of very low climatic improvements 179 during MIS 6. No major disruption or gap between the slightly pedogenized loess and the 180 non-pedogenized sediment have never been observed on the field.

\subsection{Contributions of Villiers-Adam and La Cotte de Saint Brelade sites}

These two sites, previously studied by Locht et al. (2003) and Callow and Cornford (1986) are mainly interesting for the distribution of their faunas. The main results of these studies are shortly summarized below.

\subsubsection{The Villiers-Adam site (Paris Basin)}

The site of Villiers-Adam is located in the Paris basin at $35 \mathrm{~km}$ north of Paris city (Fig. 1). Various sections were studied in this area. The Upper Saalian has been particularly studied in detail in the site of Le Chamesson. Although the main purpose of these studies concentrated on archaeology, researches in stratigraphy, geochronology and malacology (Limondin-

194 Lozouet and Gauthier, 2003) were also undertaken. In this area Saalian as well as Weischselian sections were sampled. For more details the reader can refer to a comprehensive paper published by Locht et al. (2003).

- Main characteristics of the Upper Saalian section at Le Chamesson of the formation corresponds with a contact between a carbonate-free interglacial sandy and clayish loam (a truncated Bt luvisol) and a reworked sandy loam marking the beginning of the 
Upper Saalian (Locht et al., 2003). The abrupt upper limit with the Eemian is located at the

204 boundary between typical calcareous loess and a non-calcareous loam (Bt horizon of the 205 15a/b soils) (Locht et al., 2003). Between these two limits and overlying a layered stony and 206 sandy formation, the typical calcareous loess accumulated.

207 Only the carbonated loess of Le Chamesson contains molluscs (units 16 and 17) (Limondin208 Lozouet and Gauthier, 2003) (Fig. 3B). The diversity of the molluscs is very low since only 209 five taxa were found. Like in Nantois, the best-represented taxon is Pupilla muscorum, typical 210 of open and dry environments well represented in central and Western Europe (Kerney and 211 Cameron, 1999). It is followed by the mesophyll Trichia hispida that lives in versatile 212 environments except in very dry biotopes. Limacidaes are well represented and witness of a 213 relative local moisture. The other species are Succinella oblonga and an aquatic gastropod 214 Lymnaea truncatula. Because of the poor number of species it was suggested that gastropods 215 were living in an environment difficult to colonize (Limondin-Lozouet and Gauthier, 2003) 216 but relatively stable since their number increased upwards. In general this association (Pupilla 217 muscorum, Trichia hispida and Succinella oblonga) is considered to be typical of a 218 Pleniglacial steppe loess environment (Puisségur, 1976). The paucity in gastropod species is 219 even larger than in Nantois, maybe because this outcrop was more continental and thus far 220 from the warming effects of the Saalian Sea (Fig. 1). The assumption that "the paucity" of the 221 malacologic assemblage is typical of the Western part of France" (Rousseau et al., 1990) is 222 not fully supported by the results obtained in Nantois since there are more gastropod species 223 in Nantois than in Villiers-Adam.

224 The total number of gastropod shells was calculated with the same technique as in Nantois, it 225 clearly shows that the living conditions were harsher in Villiers-Adam (Fig. 3). In the present 226 study, the total number of gastropod shells was calculated after the data of Limondin-Lozouet 227 and Gauthier (2003). Here again, the total number of terrestrial taxa increases when the 228 number of Limacidae is increasing, which evidences the role of moisture in shells 229 development. Indirectly, this result also supports the existence of brief warming and humid 230 episodes.

231 Taking account of data already published (Limondin-Lozouet and Gauthier, 2003) we 232 delineated a series of malacozones following the same criteria as those defined for Nantois 233 (Fig. 3B). The subdivision in sub-malacozones which enhance the importance of some taxa 234 will not be discussed since we are mainly interested in this paper in the total amount of shells. 235 1/ Malacozones $\mathrm{a}_{1}, \mathrm{~b}_{1}$ and $\mathrm{c}$, correspond with milder climatic conditions. The environment 236 was less dry than during stages $a_{2}$ and $b_{2}$. The landscape which probably prevailed during the 
accumulation of these deposits corresponded with open habitats rich in vegetation cover and

238 possibly with bushes and trees. 2/ Malacozones $\mathrm{a}_{2}$ and $\mathrm{b}_{2}$ suggest dryer climatic conditions.

239 The landscape which probably prevailed during the accumulation of these deposits

240 corresponded with an open habitat, some vegetation cover and possibly bushes and trees in

241 depressions. In total and, like in Nantois, we can observe the alternation between cold

242 environments (which did not favour the development of molluscs) and milder climatic

243 conditions (which generated a larger shells production).

244 The physical and chemical study of the sediment evidenced, like in Nantois, a decalcification

245 of the uppermost part of the Upper Saalian under the Eemian soil. The isotopic interpretation 246 of the organic matter sampled in the same zone support the existence of a very dry 247 environment (Locht et al., 2003) which is not fully compatible with the study of the mollusc 248 community (presence of many Limacidae and of an aquatic gastropod - Limondin-Lozouet 249 and Gauthier, 2003). This apparent discrepancy could be explained if the malacological study 250 concentrated locally on deposits neighbouring a valley or a small depression. The erosive 251 limit of the lower part of layer 18 and the abrupt contact of the base of level 17 as well as the 252 slope imaged at depth on this section may support this possible interpretation.

253 The TL-IRSL ages obtained on loess deposits have been considered as over or underestimated 254 when compared with the regional environment. An estimation of the possible ages, based on 255 the SPECMAP/GRIP-CISPII data was proposed (Locht et al., 2003). The origin of the 256 underestimated ages observed in some pedo-complexes has been already discussed elsewhere 257 by Frenchen (1999).

Fig. 3 here

\subsubsection{La Cotte de Saint Brelade site (Jersey Island)}

This very important site located at the southwest corner of Jersey Island and at $50 \mathrm{~km}$ north of the onshore Nantois site (Fig. 1) was mainly excavated for archaeology but was also studied for sedimentology, palaeontology and geochronology. We will summarize here the salient points of this site and mainly those that are useful for a comparison with the two sites described above, even if shells were not taxonomically determined at this place. This site which was inhabited by Neanderthals during various periods corresponded with a massive rock arch that was partly filled by a great volume of loess deposits. 
273 Because the Pleistocene stratigraphy of this site was established progressively during the successive archaeological excavations we will present only here a simplified reconstitution (Fig. 4) based on the global synthesis of Callow and Cornford (1986).

276 The Upper Saalian corresponds to the stage III of the authors in which they recognized 5 277 different periods ranging between units 13 and 21. The lower limit of the Upper Saalian 278 which is made of a typical loess deposited in extremely cold conditions (it is associated with 279 the rodent Dicrostonyx) is in contact with the upper part of the MIS 7 formation made of disturbed occupation floors showing a granitic sand matrix with few large blocks. The upper limit of the Upper Saalian made of soliflucted and cryoturbed loess containing on top Juniperus and Hipppophae rhamnoides pollen (indicating the beginning of a climatic improvement) passes to the Eemian (characterized by a clear pedogenesis and the beginning of a marine transgression). The stratigraphic description of the site suggests that there was a more or less continuous loess sedimentation between these two limits. Layer 15 is characterized by the presence of oak charcoal and layer 18 by Quercus, Fraxinus and Ulmus which suggest the existence of a well-expressed climatic "warming". The presence of a high herbaceous percentage in this layer is also questionable (A. Shaw, oral communication).

Even if some reworking of the deposits have been suggested in the upper and lower parts of stage III (Callow and Cornford, 1986), the presence of two well expressed episodes of climatic "warming" alternating with three periods of strong gelifluction with permafrost and cold-living rodents seems to be clear even if not totally equivalent with the four warming stages evidenced in Nantois and in Villiers-Adam. This can be partly explained by the erosional surfaces separating the $14^{\text {th }}$ and $15^{\text {th }}$ climatic episodes.

If the "limons à doublets" observed during episode 20 in La Cotte de Saint Brelade is more or less equivalent to the "limons à doublets" observed in Nantois we may correlate these two climatic improvements with the two uppermost warmings observed in Nantois and VilliersAdam, but this correlation is questionable because the "limon à doublets" of Jersey developed during a very cold episode after the illustration of Callow and Cornford, (1986) (Fig. 4: G).

It is important to underline that rodents Sicista sp., Dicrostonyx torquatus (Pallas, 1778), 
Microtus malei (Hinton, 1927), Microtus arvalis (Pallas, 1779) and Microtus gregalis (Pallas,

306 1779) collected in the Upper Saalian sediments were living in temperatures ranging between $45^{\circ}$ and $+15^{\circ}$ (Chaline and Brochet, 1986). On the contrary the presence of Quercus suggests milder temperatures since the ideal root temperature for the normal development of Quercus robur (Linnaeus, 1753) is known to be around $25^{\circ} \mathrm{C}$ ( $\mathrm{Lyr}$ and Garbe, 1995), the ideal temperature for Quercus development being around $13^{\circ} \mathrm{C}$ (Rodrigues, 2009).

311 The simultaneous presence of bones of reindeer and of oak during episode 15 and the 312 existence of "cold" and "warm" remnants in other layers, show that the original deposits have 313 been locally disturbed. This reworking is also clear where rodents, typical of taiga, were mixed with rodents living in a tundra environment (A.Yakolev, written communication). Finally, the main contribution of the palaeontological study of La Cotte de Saint Brelade is not to demonstrate the existence of a well-established stratigraphy but rather to show that it existed "warmer" phases during the very cold Late Saalian episode. This type of large climatic contrasts is usually impossible to estimate with the mere presence of mollusc taxa which are more sensible to moisture than to temperature differences.

Fig. 5 here

This part of the stratigraphy of La Cotte de Saint Brelade is suspect to some archaeologists working in Northern Brittany. They consider that oaks and other deciduous trees could not survive in Jersey during the Upper Saalian (Y. Chantreau, oral communication). They consider that the discovery of oak and pollens of deciduous trees may result from a sedimentary pollution originating in the overlying Eemian. In the absence of a definitive conclusion, we must keep in mind that the different ingressions coming from the Western English Channel were reaching the -60 and -70 metres during the highest MIS 6 sea levels (Waelbroeck et al., 2002), bringing warmer water to Jersey and Cotentin shores (Fig. 5).

\section{The offshore data (Celtic Sea)}

Over the last decades, several high resolution marine archives have been obtained at the outlet of the paleoriver "Manche" allowing to reconstruct and improve the deglacial history of the two last Terminations (Zaragosi et al., 2001; Mojtahid et al., 2005; Eynaud et al., 2007; Penaud et al., 2009; Toucanne, et al., 2009, 2010). Amongst these marine archives, a specific 
mainly routed via the paleoriver "Manche" (Toucanne et al., 2010). Actually, laminated deposits attributed to high meltwater discharges have been identified coherently and synchronously to each Terminations (Eynaud et al., 2007; Penaud et al., 2009). Among the key sites sampled on the Celtic margin, cores MD 03-2692 represents the most complete record, registering systematic laminae deposits well stratigraphically constrained.

\subsection{Core MD 03-2962}

Core MD 03-2962 was retrieved at the western side of the Trevelyan escarpment (northern Bay of Biscay) (Fig. 1) at 4064 m water-depth during the SEDICAR cruise on-board the RV Marion Dufresne II. This long hemi pelagic core nearly 40 meters long covers the last $360 \mathrm{ka}$ (Mojtahid et al., 2005). The stratigraphy of this core was established thanks to a direct comparison with the SPECMAP stable $\delta^{18} \mathrm{O}$ record. For this paper the possibility of updating the MIS 6/MIS 5 section by comparisons with the LR04 age model (Lisiecki and Raymo, 2005) could have been proposed but no revision was made because of the good coherency obtained when comparing with the ages of the SPECMAP/ LR04 references records (Fig. 6).

Fig. 6 here

- Main characteristics of the Upper Saalian section of MD 03-2692 core

This section located between 2000 and $2900 \mathrm{~cm}$ in the core, comprises a thick interval of laminated sediments spreading over $150 \mathrm{~cm}$ and corresponding to the Upper Saalian / Eemian transition. These laminae actually correspond to the onset of the European ice-sheet penultimate deglaciation and coincide with the first insolation maxima (Eynaud et al., 2007; Penaud et al., 2009) marking the Termination 2 inception. They were synchronous to/or ended a drastic cooling event at the sea-surface of the Bay of Biscay as testified by the nearly monospecific abundances of the polar taxa Neogloboquadrina pachyderma (sensu stricto. i.e. sinistral form $N p s$ ) at that time. Following their occurrence, a progressive warming which preceded the MIS 6/MIS 5 interglacial shift can be observed. It is however interrupted by various transient laminae/ Nps events, the later and most pronounced of them being assimilated to the Zeifen-Kattegate climatic oscillation (Seidenkrantz et al., 1996; McManus et al., 2002). 
dates between 0 and $30 \mathrm{ka}$. Radiocarbon ages were calibrated to calendar years before present (yr BP) using the CALIB programme (version 5.1.0 with the MARINE 04 data set). Beyond that age range, the stratigraphy has been constrained by stable isotope and carbonate content measurements which were tied to the SPECMAP delta ${ }^{18} \mathrm{O}$ reference curve (Martinson et al., 1987). The software used ispepifor this peak to peak correlation was the "AnalySeries" software (Paillard et al., 1993). Stable isotope carbonate, and light reflectance records obtained on

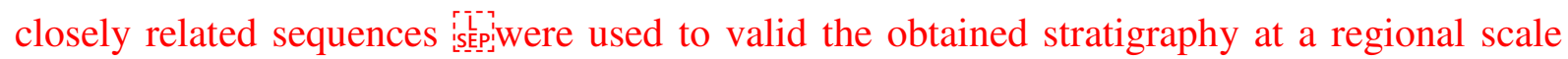
(see Mojtahid et al., 2005; Eynaud et al., 2007 for methodological details).

381

382

The synchronicities of laminae deposits and of Nps excursions in the MD 03-2692 record suggest important local advections of melt waters coming mainly from the proximal BritishIrish Ice sheet which was waning at that time. The nearly monospecific values of $N p$ s could be, at a first glance, considered as resulting from a southward migration of the polar front over the Celtic margin (Eynaud et al., 2009) and thus related to freezing sea-surface conditions (less than $10^{\circ} \mathrm{C}$ ) in summer. However these fauna excursions occurred concomitantly with large amounts of melt water associated with positive sea-level changes, which support the existence of local "warmings", which could have mitigated the continental temperatures inland (Mojtahid et al., 2005; Eynaud et al., 2007).

\section{Methodology}

\subsection{Normalization of data}

Onshore, the studied sites are characterized by Upper Saalian formations of different thicknesses. Field studies show that there are no major gaps or erosion during their deposition except in Jersey, which will not be incorporated in our comparison for this reason. In order to better compare the different malacological and sedimentological (laminae) signals their thicknesses have been normalized. The normalization assumes a constant thickness between the upper and lower Upper Saalian limits. It is responsible for a deformation of the wavelength of the original signals but is necessary if we want to check the possible simultaneity of the main malacological pulses respect with the upper and lower limits of the Late Saalian. Because this normalization does not change the amplitude of the original signal, but only its wavelength, we can observe that the malacological production of the Late Saalian of Nantois is far better developed than that observed in Villiers-Adam (Fig. 7). This higher 
malacological production also corresponds with a site which was closer to the Late Saalian

407 limits of the sea, Villiers-Adam being more continental (Fig.1). The accuracy of the

408

409

410

411

412

413

414

415

416

417

418

419

420

421

422

423

424

425

426

427

428

429

430

431

432

433

434

435

436

437

438 correlations that will be now proposed depends on the precision of the measure of the thicknesses of the sampled layers. Errors will be very limited if the thickness of the considered section is close to the normalization module (Nantois site) but can be a little bit larger if we are dealing with a section showing a compress stratigraphy like in Villiers-Adam. After normalization of the onshore data all the sections have been fitted to the offshore Upper Saalian limits in order to display a regional pattern of the warming events typical of MIS 6 in westernmost Europe.

\subsection{Tentative dating of the warming episodes}

Because all the ages previously calculated for Villiers-Adam site have been discarded (Locht et al., 2003) we will first only correlate the offshore and Nantois "warming" episodes.

- The "limon à doublets" of Nantois (Monnier et al., 1997; Danukalova et al., 2017)) and the younger group of offshore "laminae" (Eynaud et al., 2007) have been both attributed to the Zeifen-Linexert Interstadial (Seidenkrantz et al., 1996) known in many places in the Northern Hemisphere. They both correspond with the youngest "warming phase" followed by a short cooling phase which just predate the Eemian episode. It is, thus, its stratigraphical position which helps to attribute an age to this climatic improvement. An age close to $140 \mathrm{ka}$ was adopted both onshore (Van Vliet-Lanoë and Guillocheau, 1995) and offshore (Eynaud et al., 2009).

- The US-ESR measurement of a bone of Bos primigenus extracted from the boundary between a loessy head and the loess formation (corresponding to layer 35 on figure $2 \mathrm{~A}$ or to the upper part of layer 4 on figure $2 \mathrm{~B}$ ), superimposed to the base of the second "warming" episode of Nantois, delivered an age of $166 \pm 8$ ka (US-ESR by Bahain et al., 2012). This "warming episode" also corresponds to the penultimate group of "laminae" of core MD 032692 dated at around 164 ka by SPECMAP $\delta^{18} \mathrm{O}$ benthic record (Eynaud et al., 2007).

- In between, there is no onshore criterion to date the overlying "warming" episode "(Fig. 7: c) but it is perfectly in line with the largest group of "laminae" dated offshore at around 148 ka by SPECMAP (Eynaud et al., 2007). This prominent offshore "warming" signal was also contemporaneous with the largest group of Neogloboquadrina pachyderma which was associated with an active icebergs melting (Eynaud et al., 2009). 
- At last, there is no onshore data to date the oldest "warming" phase which can be dated at around 182 ka after SPECMAP data (Eynaud et al., 2007).

Fig. 7 here

\subsection{Correlation between biological and sedimentological data}

The methodology to locate the biological and sedimentological peaks and the technique used to delineate the "warming" stripes must be clearly separated:

a/ The location of the different peaks is the direct result of the shells and laminea numbering. Their location is perfectly determined respect with the upper and lower stratigraphical limits recognized during the field study (they correspond with the intra-Saalian-Upper Saalian boundary and with the Upper Saalian-Eemian contact). Two of these peaks have been dated at 140 and 166 ka by direct ("warming" b) or indirect ("warming" d) dating and by offshore SPECMAP correlation. The age of the two other peaks is only known after comparison with the offshore SPECMAP data (see the previous paragraph). The location of the peaks relies consequently on two different types of information.

b/ The "warming" signals are different in nature, wavelength and shape and there is no possible common rule to draw the "warming" stripes summarizing the regional climatic changes. These correlations are only based on a visual system. Because this system is not based on any calculation, the upper and lower boundaries of the "warming" stripes may not be totally accurate. However, the correlations adopted for this publication, are strengthen by the excellent fits which can be observed with the Late Saalian "warming" episodes recognized in the Batajnica cliff (Serbia) (Osipova et al., 2013) and with the variations of the sea surface temperatures recorded in the North Atlantic core M23414 (Kandiano, 2002).

\subsection{Correlations at the global scale}

The increasing production of shells from East to West (Fig. 7) during relatively short periods suggests a possible influence of the sea. This gradient can be either attributed to the modification of the North Atlantic thermo-hyaline circulation since the course of the Gulf Stream changed as a function of the position of the Polar Front (Mörner, 1996). But it can be also associated with the existence of short-living marine invasions of the palaeo-Manche system (palaeo-English Channel) during abrupt and short ice melting phases (Fig. 5). It is the 
reason why the contemporaneous variations of the sea level have been checked. Figures $8 \mathrm{~b}$ and c show the evolution of the sea level during this episode (Waelbroeck et al., 2002). This curve, based on the oxygen isotopic ratios of the benthic foraminifera sampled in the North Atlantic and equatorial Ocean, was completed by the data of Shackleton (1987) which display more details for the recent geological periods (see the green curve).

Fig. 8 here

Figures 8a and c clearly show that the "warming" episodes occurred at the same time as the four positive oscillations of the Late Saalian Sea. This correlation is confirmed by the evolution of the temperatures recorded in EPICA and VOSTOK boreholes (Berruyer, 2013) (Fig. 8d). We completed these figures with the $\delta^{18} \mathrm{O}$ values measured in the MD 03-2692 offshore Celtic Sea core, which visually strengthen the proposed correlations (upper part of Fig. $8 \mathrm{a}$ and $b)$.

\subsection{Correlations with the astronomical cycles}

Correlations between the four Late Saalian "warming" episodes and the astronomical parameters recognized by Milankovitch (1904) reveal a reasonable fit with most of the data. However, for a better precision, the correlations were made with the variations of the astronomical cycles calculated by Berger and Loutre (1991) showing their impact on the boreal hemisphere insolation (July insolation at 15 and $65^{\circ} \mathrm{N}$ ). The most recent "warming" (Fig. 9: d) perfectly fits with a precession maximum and a minimum insolation. Warming c can be correlated with an insolation maximum and a precession minimum (Fig. 9: c). "Warming" b displays the same characteristics as warming d (Fig. 9: b). At last, warming a does not fit with any major astronomic signal but corresponds with the mid-amplitude of a positive insolation phase and with the mid-amplitude of a precession maximum (Fig. 9: a). The addition of the effects of both signals being probably responsible for the first warming episode observed during the Late Saalian climatic oscillations. These correlations are still valid even if we take account of the small uncertainties attached to the upper and lower limits of the "warming" episodes since the wavelengths of the insolation and of the precession cycles are much larger than these uncertainties. 


\section{Scientific results}

Taken as a whole, sedimentary and biological markers permitted to recognize four phases of

511 low "warming" during MIS 6. These "warming" episodes were contemporaneous with four

512 positive variations of the sea level and with four variations of the astronomical cycles.

513 Indirect ("limon à doublets") and direct (US-ESR) dating permitted to correlate two of these

514 episodes with the offshore stratigraphy characterized by clear evidences of contemporaneous

515 ice melting. This discovery was the opportunity to check the hypothesis of a possible

516 relationship between the irregular dwelling of Neanderthals in Brittany and the short climatic

517 improvements.

\section{Discussion}

This short discussion will be devoted to the possible relationship between the irregular dwelling of Neanderthals in Brittany and the short MIS 6 climatic improvements.

\subsection{Compilation of Neanderthals sites}

526 Three main Neanderthal sites are now dated in Brittany; they are all located in Northern

527 Brittany close to Nantois cliff (Fig. 5).

528 - The Nantois site is a typical Palaeolithic site corresponding to a hunting rest area that evidences well preserved cut up remnants. The archaeological layer (layer 35, Fig. 2A) located $20 \mathrm{~m}$ below the Eemian paleosoil delivered few Mousterian artefacts and a bovid bone

531 (Monnier, 1986). Clear stratigraphic similarities with nearby sites where radiometric dating 532 has been carried out (Bahain et al., 2012), confirm the general chronostratigraphic scheme 533 previously suggested on the basis of field observations and major stratigraphic landmarks

534 (Monnier et al., 2011). Recent measurements show that layer 35 can be dated at $166 \pm 8 \mathrm{ka}$ 535 (Bahain et al., 2012).

536 -The $15 \mathrm{~m}$ thick stratigraphic sequence of Piégu site is made of 14 layers indexed from A to $\mathrm{N}$ 537 from the bottom to the top. It incorporates two beach deposits (units D and H) considered as remnants of high sea levels during interglacial stages (Hallégouët et al., 1993). The sequence includes also an interglacial palaeosoil (unit K) and several archaeological layers (units D, F, $\mathrm{G}$ and $\mathrm{J}$ ) with a Mousterian lithic industry and, for some of them, paleontological remains. 
541 Layer $\mathrm{G}$ is the main archaeological level; it corresponds to a "head" deposit (a periglacial 542 solifluxed frost shattered debris assemblage deposited during a glacial stage) (Danukalova et 543 al., 2015). This level delivered Mousterian flint flakes and a fossil fauna assemblage 544 indicating a wet temperate climate and a forested environment with local grasslands. Layer G can be correlated with late MIS 7 or early MIS 6, with a quadratic mean age of $193 \pm 6 \mathrm{ka}$

546 (Bahain et al., 2012). The archaeological assemblage witnesses the existence of a human 547 occupation on top of the cliff during an interglacial stage, in accordance with the 548 biochronological framework of Northern France (Auguste, 2009). The date proposed by 549 Monnier et al. (2011) for level J is confirmed by the dating results. Lastly, the Piégu's marine level $\mathrm{H}$, with a quadratic mean age of $122 \pm 23 \mathrm{ka}$ can be attributed to Eemian (MIS 5e), by US-ESR dates.

-The shelter-cave of Grainfollet is known for many years. It is made of two very close but different units. The archaeological unit corresponds with a river shelf located at the foot of a rocky cliff. On the shelf itself two remnants of fires associated with charcoals, burnt bones and many artefacts have been sampled. It is not completly sure that some of the observed Palaeolithic remnants have not been partly disturbed by solifluxion or by the tides (Monnier, 1982). The cliff is made of an alternation of loam, loess and stony levels. This area which probably corresponded with a butchery was initially considered to be of Wûrm 1 age (Giot and Bordes, 1955). Recent reappraisal of the cliff permitted paleo-densimetry measurement as well as dating on bones and teeth (Laforge et al., 2018). Six ages were calculated, but one was discarded because of the bad preservation of a tooth, they can be divided in two groups ranging between 138 and $171 \mathrm{ka}$.

\subsection{Improvement of the age error bars}

566 Comparison between the different ages dating the MIS 6 occupation of Neanderthals in Brittany evidences large error bars. These error bars are often larger than the duration of the "warming" episodes. However, the ages which were finally retained for publication (Bahain et al., 2012), almost always perfectly fit with the "warming" episodes. If we take account of the error bars this excellent superimposition (based on 14 dated sites) is surprizing. It is why the error bars have been recalculated (Ludwig, 2000), not only for individual ages but also for the three groups of dates showing neighbouring ages (Fig. 10). Two solutions can be considered, depending on the dating techniques. It seems that the 2 sigmas solution can be selected for the sites studied in northern Brittany. 
Fig. 10 here

\subsection{Possible correlation between the "warming episodes" and the age of Neanderthal sites}

579

The left column of Fig. 10 shows the superimposition of the "warming" episodes onto the age of the Neanderthal sites with no error bars. The two columns on the right side show the same superimposition after recalculation of the age error bars for the three groups of neighbouring ages. The two sigmas error bars are still a little bit large but we believe that the almost perfect superimposition of the "warming" episodes and of the mean quadratic age of the Neanderthal sites must be also considered. It is mainly because the same superimposition of data repeats 14 times that we suggest that Neanderthal migrations were possibly controlled by the successive climatic improvements recognized during MIS 6.

588 The dated "Les vallées" site located close to Nantois cliff (Fig. 5) was not considered during these correlations. This site provided ages ranging between 138 and $182 \mathrm{ka}(138 \pm 22,163 \pm$ 23 and $182 \pm 29 \mathrm{ka}$ ) on teeth (Bahain et al., 2012). Those ages which were supposed to date the same stratigraphic unit correspond, after our correlations (Fig. 7), to three different "warming" episodes questioning the correlations. However, a careful study of the technical report concerning the excavation (Huet, 2010) arises various difficulties. The indurated sand excavated for archaeology outcrops in the middle of a small plateau usually hidden under the sand and the sea. The archaeological site (which investigated only $40 \mathrm{~cm}$ of sediment) evidenced a poorly preserved horse mandible. No complete or intact bones or teeth were found. All the fauna remnants were very fragmented and often soft, fragile and deeply impregnated with salt. The spatial distribution of the pieces of bones evidenced the existence of a clear solifluction casting. Furthermore, the archaeological site was established on a sand dune which was probably more or less active at the time of its occupation by Neanderthals and a general disturbance of the site was observed after this period of occupation. If we take account of all these observations, we don't know if the large dispersal of the published ages is

603 a reality, was associated with the bad condition of preservation of the teeth or if it resulted 604 from the mixture of faunal pieces of different origins.

\section{General conclusions}

608 -Study of the frequency of loess gastropods in Brittany, of animal and vegetal fossils markers 
609 of temperatures in Jersey and of the offshore laminae, permitted to recognize four short and 610 abrupt "warming" episodes during MIS 6.

611 -The contemporaneous variations of the sea level and the evolution of temperatures recorded

612 in EPICA and VOSTOK boreholes confirm the reality of the "warming" episodes found in 613 Brittany.

614 -Measurements of marine oxygen isotopes on foraminifera and on land snails currently 615 underway show that the "warming" episodes were not all characterised by the same 616 temperature.

617 -The "warming" episodes, which were responsible for an elevation of 30 to 40 metres of the 618 sea-level generated large ingressions of seawater in the mid-Channel valley. These 619 ingressions could have been at the origin of the development of oaks in Jersey, interrupting 620 during a short period, the cold continental tundra environment characterized by lemmings.

621 -Although the ESR/U dating of the archaeological sites, recalculated for the three main group 622 of ages, are still affected by error bars a little bit larger than the duration of the "warming" 623 episodes, we believe that their systematic association might suggest a relationship between 624 the climatic improvements and the migration of Neanderthals during MIS 6.

625

\section{Acknowledgements}

628 The authors would like to express there thanks to M.Y. Daire Director of the Laboratory of 629 ArcheoSciences (University of Rennes 1, France) for welcoming J.P. Lefort and G.A. 630 Danukalova in her Laboratory. We are also indebted to S.G. Kovalev Director of the 631 Geological Institute of the Ufimian Federal Research centre for the authorization he gave to 632 G. Danukalova to work on this and future programs related with Quaternary Researches in 633 Western Europe. This work was partly achieved thanks to the State Programs N-0252-2016634 0006, 0246-2019-0118 and the Russian Government Program of Competitive Growth of 635 Kazan Federal University. The authors thank J.J Bahain, A. Shaw and A.Yakovlev for 636 scientific discussions, F. Bertin for various drawings and the reviewers of this paper for their 637 comments and improvement of the original English text.

\section{8}

639

\section{References}

640

641 Animal base, n.d. www.animalbase.uni-goettingen.de. 
642 Antoine, P., Bahain, J.J., Debenham, N., Frechen, M., Gauthier, A., Hatté, C., Limondin-

643 Lozouet, N., Locht, J.L., Raymond, P., 2003. Nouvelles données sur le Pléistocène du nord du 644 Bassin parisien: les séquences loessiques de Villiers-Adam (Val d'Oise, France) (New data on 645 the Pleistocene of the north of the Paris basin: the loess-palaeosols sequences of Villiers646 Adam (Val d'Oise. France). Quaternaire 14 (4), 219-235.

647 Astakhov, V., Shkatova, V., Zastrozhnov, A., Chuyko, M., 2016. Glaciomorphological Map 648 of the Russian Federation. Quaternary International 420, 4-14.

649 Auguste, P., 2009. Évolution des peuplements mammaliens en Europe du Nord- Ouest durant 650 le Pléistocène moyen et supérieur. Le cas de la France septentrionale. Quaternaire 20, 527651550.

652 Bahain, J.J., Falguères, C., Laurent, M., Shao, Q., Dolo, J.M., Garcia, T., Douville, E., Frank, 653 N., Monnier, J.L., Hallégouët, B., Laforge, M., Huet, B., Liouville, M., Serre, F., Gagnepain, 654 J., 2012. ESR and ESR/U-series dating study of several middle Palaeolithic sites of Pléneuf655 Val-André (Brittany, France), Piégu, Les Vallées and Nantois. Quaternary Geochronology 10, $656424-429$.

657 Berruyer, O., 2013. Historique long et analyse du réchauffement climatique. Les Crises. 658 https://www.les-crises.fr/climat-6-rechauffement-global/

659 Callow, P., Cornford, J.M., 1986. La Cotte de St Brelade 1962-1978. Excavation by C.B.M. 660 Mc Burney. Geobook. University Press. Cambridge. UK. 432 p.

661 Chaline, J., Brochet, G., 1986. The rodent fauna. In: Callow, P. and Cornford, J.M., La Cotte 662 de St Brelade 1962-1978. Excavation by C.B.M. Mc Burney. Geobook. University Press, 663 Cambridge, 139-143.

664 Danukalova, G., Lefort, J.P., Osipova, E., Monnier, J.L., 2013. Recent advances in the 665 stratigraphy of the Upper Pleistocene of Westernmost Europe: La Haute Ville and Bréhat 666 Cliffs (Northern Brittany, France). Quaternary International 284, 30-44.

667 Danukalova, G., Hallégouët, B., Lefort, J.P., Monnier, J.L., Osipova, E., 2015. Reconstruction 668 of the Middle-Late Pleistocene and Holocene palaeoenvironments of the Piégu Palaeolithic 669 site (Brittany, France) based on biostratigraphical data, Archéosciences, revue 670 d'Archéométrie 39, 7-30.

671 Danukalova, G., Monnier, J.L., Lefort, J.P., Osipova, E., Pustoc'h, F., Le Bannier, J.Ch., 672 2017. Sedimentological and malacological comparisons between the Upper Saalian and 673 Upper Weichselian loess superimposed in the Nantois cliff (France): Reconstruction of their 674 environments south of the British Ice Sheet. Archéosciences, revue d'Archéométrie 41 (2), $67563-87$. 
676 Derbyshire, E., Billard, A., Van Vliet-Lanoë, B., Cremashi, M., Lautridou, J.P., 1988. Loess

677 and paleoenvironment: Some results of a European joint programme of research. Journal of 678 Quaternary Sciences 3 (2), 147-170.

679 Eynaud, F., Zaragosi, S., Scourse, J., Mojtahid, M., Bourillet, J.F., Hall, I.R., Penaud, A.,

680 Locascio, M., Reijonen, A., 2007. Deglacial laminated facies on the NW European

681 continental margin: the hydrographic significance of British-Irish Ice Sheet deglaciation and

682 Fleuve Manche paleoriver discharges, Geochemistry, Geophysics, Geosystems 8 Q06019,

683 doi:10.1029/2006GC001496.

684 Frenchen, M., 1999. Upper Pleistocene Loess stratigraphy in southern Germany. Quaternary

685 Geochronology 18, 243-269.

686 Giot, P.R., Bordes, F., 1955. L'abri sous roche paléolithique de Grainfollet à St Suliac (Ille et 687 Vilaine). L'Anthropologie 59 (3/4), 205-234.

688 Hallégouët, B., Monnier, J.L., Gagnepain, J., 1993. Le site Paléolithique moyen de Piégu (en 689 Pléneuf-Val-André), premiers résultats des fouilles. Mémoires de la Société d'Emulation des 690 Côtes-d'Armor 121, 3-17.

691 Huet, B. 2010. Le site paléolithique moyen des Vallées (Pléneuf-Val-André, Côtes-d'Armor). 692 Internal Report UMR 6566-CReAAH. University of Rennes. France. 62 p.

693 Kandiano, E.S., 2002. Dynamics of the Ocean Surface in the Polar and Subpolar North 694 Atlantic over the last 500000 Years. Thesis University of Kiel, Germany. 90 p.

695 Kerney, M.P., Cameron, R.A.D., 1999. Guide des Escargots et limaces d'Europe. Delachaux 696 et Niestle S.A., Lausanne, 370 p.

697 Laforge, M., Bahain, J.J., Shao, Q., Falgueres, Ch., Laurent, M., Monnier, J.L., 2018. L'abri 698 sous roche de Grainfollet (St Suliac, Ille et Vilaine): chronostratigraphie et datation ESR699 U/Th d'une occupation du Paléolithique moyen en context périglaciaire. Quaternaire (in 700 press).

701 Lautridou, J.-P., 1985. Le cycle périglaciaire pléistocène en Europe du Nord-Ouest et plus 702 particulièrement en Normandie. Centre Géormophologie (ed): University of Caen; 908 p.

703 Lefort, J.P., Danukalova, G., Eynaud, F., Monnier, J.L., Osipova, E., 2017. Mise en Evidence 704 de quatre courtes périodes de réchauffement pendant le Saalien Supérieur (190 à 130 ka) en 705 Bretagne. Bulletin de la Société Géologique et Minéralogique de Bretagne D15, 35-45.

706 Likharev, I.M., Rammelmeier, E.S., 1952. Land molluscs of the fauna of the USSR. Academy 707 of Sciences of USSR Press, Leningrad, Moscow, 512 p. (Determinative tables of the USSR 708 fauna. Proceedings of the Zoological Institute of the USSR Academy of Sciences 43 (in 709 Russian). 
710 Limondin-Lozouet, N., Gauthier, A., 2003. Biocenoses Pléistocènes des séquences loessiques 711 de Villiers-Adam (Val d'Oises, France): études malacologique et palynologique. Quaternaire $71214,237-252$.

713 Lisiecki, L.E., Raymo, M.E.A., 2005. Pliocene-Pleistocene stack of 57 globally distributed 714 benthic $\delta^{18}$ O records. Paleoceanography 20, PA1003, doi: 10.1029/2004PA001071.

715 Locht, J.L., Antoine, P., Bahain, J.J., Dwrila, G., Raymond, P., Limondin-Lozouet, N., 716 Gauthier, A., Debenham, N., Frechen, M., Rousseau, D.D., Hatté, Ch., Haesaerts, P., 717 Metsdagh, H., 2003. Le gisement paléolithique moyen et les séquencess pléistocènes de 718 Villiers-Adam (Val-d 'Oise): chronostratigraphie, environnement et implantations humaines. 719 Gallia préhistoire 45, 1-111.

720 Loyer, S., Monnier, J.L., van Vliet-Lanoë, B., Hallégouët, B., Mercier, N., 1995. La coupe de 721 Nantois (Baie de Saint-Brieuc, France): datations par thermoluminescence (TL) et données 722 paléoenvironnementales nouvelles pour le Pléistocène de Bretagne. Quaternaire 6 (1), 21-33. 723 Ložek, V., 1964. Quartärmollusken der Tschechoslowakei. Rozpravy Ustredniho ustuvu 724 geologického 31, 1-374.

725 Ludwig, K.R., 2000. Isoplot/Ex, A geochronological Toolkit for Microsoft Excel. Berkley 726 Geochronology Center. Special Publication $N^{\circ} 1 \mathrm{a}$.

727 Lyr, H., Garbe, V., 1995. Influence of root temperature on growth of Pinus sylvestris, Fagus 728 sylvatica, Tilia cordata and Quercus robur. Springer Verlag, Berlin 9 (4), 220-223.

729 McManus, J.F., Oppo, D.W., Keigwin, L.D., Cullen, J.L., Bond, G.C., 2002. Thermohaline 730 Circulation and Prolonged Interglacial Warmth in the North Atlantic. Quaternary Research $73158,17-21$.

732 Martinson, D.G., Pisais, N.G., Hays, J.D., Imbrie, J., Moore, Jr.T.C., Shackleton, N.J., 1987.

733 Age dating and the orbital theory of the ice âges: Development of a high-resolution 0 to 734 300,000-year chronostratigraphy, Quaternary Research, 27, 1-29.

735 Mazeres, R., 1938. Contribution à l'étude des formations quaternaires des Côtes-du-Nord.

736 Bulletin de la Societé Géologique et Minéralogique de Bretagne, 13-16.

737 Mojtahid, M., Eynaud, F., Zaragosi, S., Scourse, J., Bourillet, J.F., Garlan, T., 2005.

738 Palaeoclimatology and palaeohydrography of the Glacial stages on Celtic and Armorican 739 margins over the last 360000 years. Marine Geology 224, 57-82.

740 Monnier, J.L., 1973. Contribution à l'étude des dépôts quaternaires de la région de Saint-

741 Brieuc. Travaux du Laboratoire d'Anthropologie - Préhistoire - Protohistoire - Quaternaire 742 Armoricains. Thèse 3ème cycle, University of Rennes 1, France, 259 p. 
743 Monnier, J.L., 1982. Le Paléolithique inférieur et Moyen en Bretagne. Habitats et économie 744 des matières premières. Bulletin de l'Association française pour l'étude du Quaternaire 2-3, $74593-104$.

746 Monnier, J.L., 1986. Le gisement paléolithique moyen de Nantois, Pléneuf (Côtes du Nord). 747 Bulletin de la société Préhistorique française 83, 146-150.

748 Monnier, J.L., Bigot, B., 1987. Stratigraphie des dépôts pléistocènes du nord de la Bretagne 749 (France), les Formations de Port-Morvan et de la Haute-Ville. Bulletin de l'Association 750 française pour l'Etude du Quaternaire 32 (2), 93-103.

751 Monnier, J.L., Van Vliet-Lanoë, B., Hallégouët, B., 1997. Nantois. Saalian loesses, Eemian 752 pedocomplex, Weichselian succession. In: The Quaternary of Brittany. Guidebook. Travaux 753 du Laboratoire d'Anthropologie. Université de Rennes 1, p. 41-46.

754 Monnier, J.L., Huet, B., Laforge, M., 2011. Application of sedimentological analysis to 755 correlation of eroded layers under beaches with local and regional Pleistocene stratigraphy: a 756 contribution to geological dating of Palaeolithic sites, northern coast of Brittany, France.

757 Quaternary International 231, 78-94.

758 Mörner, N.A., 1996. Earth Rotation, Ocean Circulation and Paleoclimate: The North Atlanic759 European case. In: Andrews, J.T., Austin, W.E.N., Bergsten, H., Jennings, A.E. (Eds.), Late 760 Quaternary Palaeoceanography of the North Atlantic Margins: an introduction. Geological 761 Society, London, Special Publications 111, 359-370.

762 Osipova, E., Danukalova, G., Markovic, S., 2013. Malacological characteristics of the Middle 763 to Upper Pleistocene transitional interval (MIS 7/5e) observed in the Batajnica locality 764 (Serbia). Quaternary International 292, 86-100.

765 Paillard, D., Labeyrie, L., Yiou, P., 1993. Macintosh program performs time-series analysis. 766 EOS Transactions. AGU 77, 379.

767 Penaud, A., Eynaud F., Turon, J.L., Zaragosi, S., Malaize, B., Toucanne, S., Bourillet, J.F., 768 2009. What forced the collapse of European ice sheets during the last two glacial periods (150 769 ka B.P. and 18 ka cal B.P.)? Palynological evidence. Palaeogeography, Palaeoclimatology, $770 \quad$ Palaeoecology 281 (1-2), 66-78.

771 Puisségur, J.J., 1976. Mollusques continentaux quaternaires de Bourgogne. Significations 772 stratigraphiques et climatiques. Rapports avec d'autres faunes boréales de France. Mémoires 773 géologiques de l'Université de Dijon 3, France, 241 p.

774 Rodrigues, A., 2009. Le chêne pédonculé face aux changements climatiques. Agro Paris775 Tech, ONF, $63 \mathrm{p}$.

776 Rousseau, D.D, Puissegur, J.J., Lautridou, J.P., 1990. Biogeography of the Pleniglacial 
malacofaunas in Europe. Stratigraphic and climatic implications. In: Rousseau, D.D. (Ed.).

778 Methods and concepts in European stratigraphy. Palaeogeography. Palaeoclimatatology. Palaeoecology 80, 7-23. Seidenkrantz, M.-S., Bornmalm, L., Johnsen, S.J., Knudsen, K.L., Kuijpers, A., Lauritzen, S. -E., Leroy, S.A.G., Mergeal, I., Schwegeer, C., Van Vliet-Lanoë, B., 1996. Two-step deglaciation at the oxygen isotope stage 6/5e transition: the Zeifen-Kattegat climate oscillation. Quaternary Science Reviews 15, 63-75. Shackleton, N.J., 1987. Oxygen isotopes, ice volume and sea level. Quaternary Science Reviews 6, 183-190.

Shileyko, A.A., 1984. Land molluscs of the Pupillina (Gastropoda, Pulmonata, Geophila). Nauka Press, Leningrad, 399 p. (Fauna of the USSR. Mollusca, vol. 3, Issue 3) (in Russian). Sümegi, P., Krolopp, E., 2002. Quartermalacological analyses for modeling of the Upper Weichselian palaeoenvironmental changes in the Carpathian Basin. Quaternary International 91, 53-63. Svendsen, J.I., Alexanderson, H., Astakhov, V.I., Demidov, I., Dowdeswell, J.A., Funder, S., Gataullin, V., Henricksen, M., Hiort, C., Houmark-Nielsen, M., Hubberten, H.W., IngaIfsson, O, Jakobsson, M., Kjaer, K. H., Larsen, E., Lokrantz, H., Lunkka, J. P., Lysav, A., Mangerud, J., Matiouchkov, A., Murray, A., Maller, P., Niessen, F., Nikolskaya, O., Polyak, L., Saarnisto, M., Siegert, C., Siegert, M.J., Spielhagen, R.F., Stein, R., 2004. Late Quaternary ice sheet history of northern Eurasia. Quaternary Science Review 23, 1229-1271. Toucanne, S., Zaragosi, S., Bourillet, J.F., Gibbard, P.L., Eynaud, F., Giraudeau, J., Turon, J.L., Cremer, M., Cortijo, E., Martinez, P., Rossignol, L., 2009. A 1.2 Ma record of glaciation and fluvial discharge from the West European Atlantic margin. Quaternary Science Reviews 28 (25-26), 2974-2981.

801 Toucanne, S., Zaragosi, S., Bourillet, J.F., Marieu, V., Cremer, M., Kageyama, M., Van Vliet802 Lanoë, B., Eynaud, F., Turon, J.L., Cortijo, E., Gibbard, P.L., 2010. The first estimation of 803 Fleuve Manche palaeoriver discharge during the last deglaciation: Evidence for 804 Fennoscandian ice sheet meltwater flow in the English Channel ca 20-18 ka ago, Earth and 805 Planetary Science Letters 290 (3-4), 459-473.

806 Van Vliet-Lanoë, B., Guillocheau, F., 1995. Evolution de l'enregistrement pédosédimentaire 807 depuis 150 ka en Europe du Nord-ouest: biorhexistasie et bilans sédimentaires. Comptes 808 Rendus de l'Académie des Sciences, Paris, 320, IIa, 419-426.

809 Waelbroeck, C., Labeyrie, L., Michel, E., Duplessy, J.C., McManus, J.F., Lambeck, K., 810 Balbon, E., Labracheri, M., 2002. Sea-level and deep water temperature changes derived from 
811 benthic foraminifera isotopic records. Quaternary Science Reviews 21, 295-305.

812 White, D., Preece, R., Shchetnikov, A., Parfitt, S., Dlussky, K., 2008. A Holocene molluscan 813 succession from floodplain sediments of the upper Lena River (Lake Baikal region), Siberia.

814 Quaternary Science Reviews 27, 962-987.

815 Zaragosi, S., Eynaud, F., Pujol, C., Auffret, G.A., Turon, J.-L., Garlan, T., 2001. Initiation of 816 the European deglaciation as recorded in the northwestern Bay of Biscay slope environments

817 (Meriadzek Terrace and Trevelyan Escarpment): a multi-proxy approach, Earth and Planetary 818 Science Letters 188(3-4), 493-507.

\section{Captions}

Figure 1. Location of the four sites where MIS 6 sections have been recognized west of Europe. The sites are shown at the time of the maximum Late Saalian regression. LCSB: La

824 Cotte de Saint Brelade; MD 03-2692: Celtic Sea core; N: Nantois; Va: Villiers-Adam. Black arrows: direction of the katabatic winds. Vertical ruling: British Ice Sheet.

Figure 2. Stratigraphy and frequency of the various terrestrial molluscs observed in loess of the Nantois Formation (Saalian) of Nantois site. A: Nantois cliff section: stratigraphic sequence according to Monnier (1973). Small Arabic numbers indicate the initial numbering of the lithological units. B: Re-investigated loess interval (Upper Saalian). Numbers correspond to the total land snail shells found in each sample. Symbol + indicates shells detritus found in samples. Lithology: 1: soil (A horizon); 2: soil (B horizon); 3: colluvium (angular rocky fragments) (=head); 4: loess or loess-like loam; 5: loamy sand; 6: sand; 7: basement; 8: pebble; 9: loam; 10: published age; 11: incipient soils observed on the field. Granulometry and $\mathrm{CaCO}_{3}$ data are shown. f: limit of decalcification; g: calcareous concretions. LAD: "Limon à doublets". The small stratigraphic differences observed between sections A and B result from the erosion of the cliff during the last 40 years. For more details see Danukalova et al., 2017.

Figure 3. A: Synthetic stratigraphic section of Villiers-Adam at Le Chamesson after Antoine in (Locht et al., 2003). B: Section sampled for malacology, reinterpreted after the data published by Limondin-Lozouet and Gauthier (2003). Numbering of the different layers by

843 Antoine (Locht et al., 2003). Simplified caption: 1: Sandy loam; 2: Sandy and clayish loam;

844 3: Stony and sandy layer; 4: Calcareous loess; 5: Sand; 6: Layered calcareous loess (niveo- 
845 eolian sediment with small ice-drying cracks); 7: Layer number; 8: Stony and sandy layer

846 (heterometric stones association made of grindstones mixed in a brown and red clayish sand 847 matrix). The total number of each shell taxon is given for 10 kilos of sediment. Small letters $848 \mathrm{a}_{1-2}, \mathrm{~b}_{1-2}$ and $\mathrm{c}$ are malacozones and subzones according to Limondin-Lozouet and Gauthier 849 (2003) with authors' additions.

850

851 Figure 4: Synthetic Upper Saalian section of La Cotte de Saint Brelade (Jersey Island) taken 852 directly from Callow and Cornford (1986). Note the place of the erosion levels and the 853 alternation between "cold" and "warm" fossil remnants

855 Figure 5. Extension of the Western English Channel ingressions during the different MIS 6 856 "warming" episodes. The archaeological sites of Northern Brittany and Jersey are shown. Sea 857 contours after P. Stephan, IUEM Brest (slightly modified).

859 Figure 6. Multiproxy data measured in core MD03-2692 sampled in Celtic Sea. XRF ratio of $860 \mathrm{Ca} / \mathrm{Fe} ; \delta^{18} \mathrm{O}$ benthic record; $\mathrm{N}^{\circ}$ of laminae /cm; CLG c.: coarse lithic grain concentrations 861 and relative frequencies (\%) of the polar species Neogloboquadrina pachyderma. Note that 862 the comparison with the SPECMAP $\delta^{18} \mathrm{O}$ benthic record (Martinson et al., 1987 at $863 \mathrm{ftp} / /$ ftp.ncdc.noaa.gov/pub/data/paleo/paleocean/specmap) and the LR04 $\delta{ }^{18} \mathrm{O}$ benthic stack 864 (Lisiecki and Raymo, 2005) underlines the robustness of the MD03-2692 age model

865 (Mojtahid et al., 2005). ZK: Zeifen-Kattegate episode.

867 Figure 7. Correlation between laminae and the different biological peaks recognized in the 868 Upper Saalian of Westernmost Europe; LAD: "Limon à doublets"; a, b, c, d: Correlation 869 stripes. Large numbers: Direct and indirect dating of the "warming episodes".

871 Figure 8. Comparison between the four "warming" episodes that affected the Late Saalian 872 glacial stage and the contemporaneous variations of the sea level. a: Variations of the sea873 level during the last $450 \mathrm{ka}$ after Waelbroeck et al. (2002) (black curve) completed by the 874 Shackleton's (1987) sea-level curve for the younger periods (in green), b: enlarged sketch for 875 the period of interest. $\delta^{18} \mathrm{O}$ values measured offshore (MD 03-2692) are also shown. c: 876 Correlation between laminae and the different biological peaks shown on figure 7; LAD: 877 "Limon à doublets". d: Evolution of temperatures recorded in EPICA and VOSTOK 878 boreholes during MIS 6. Inset: photograph of a "limon à doublets" facies. 
880 Figure 9. Comparison between the four "warming episodes" recognized during the Late

881 Saalian and the orbital parameters computed by Berger and Loutre (1991). A: Correlation 882 between biological peaks and laminae; B: Orbital parameters.

883

884 Figure 10. Comparison between MIS 6 "warming episodes" and Neanderthal dwellings. Left 885 column: ages of the various Neanderthals sites measured in Brittany during MIS 6 (Bahain et 886 al., 2012) superimposed onto the four "warming" episodes recognized onshore with no error 887 bar. Right columns: Calculation of error bars after the ISOPLOT software (Ludwig, 2000). 888

889 Table 1. Composition of the mollusc species recognized in the Nantois formation. 890 891 


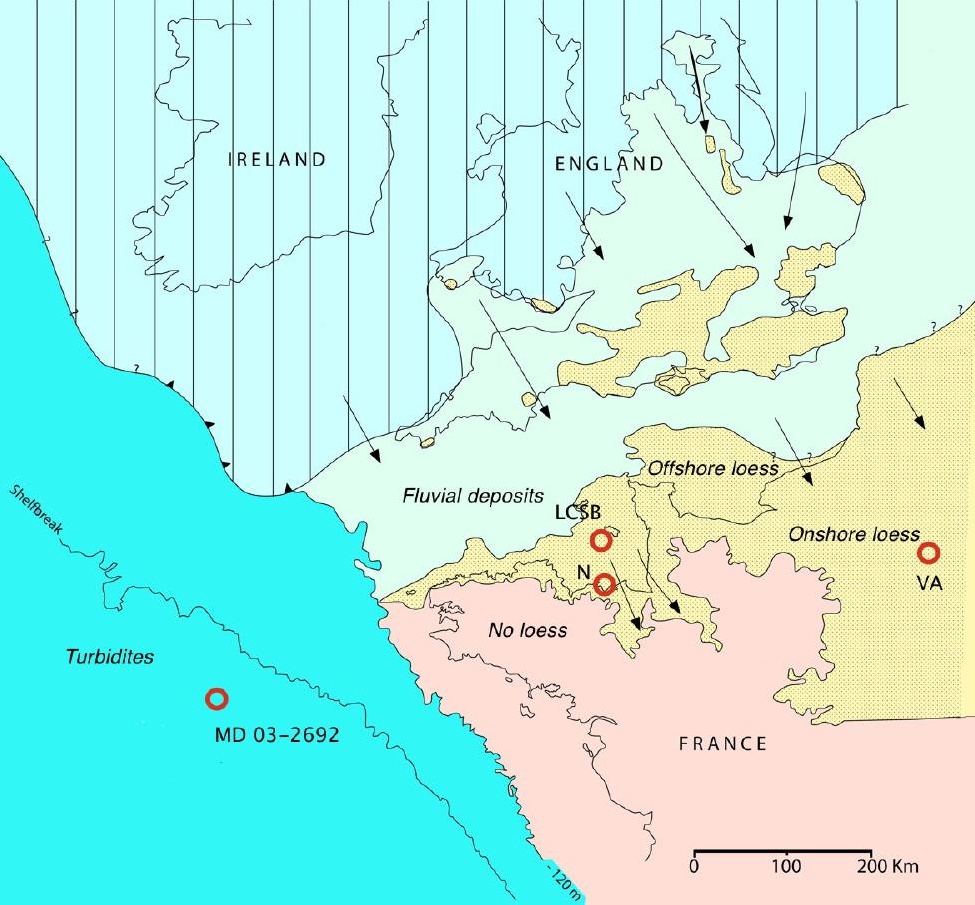




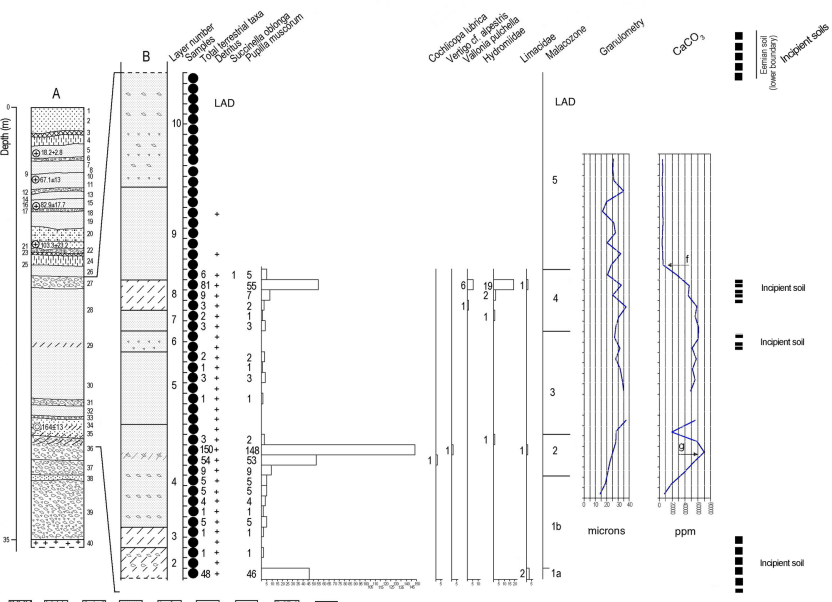

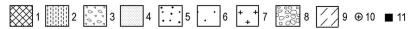




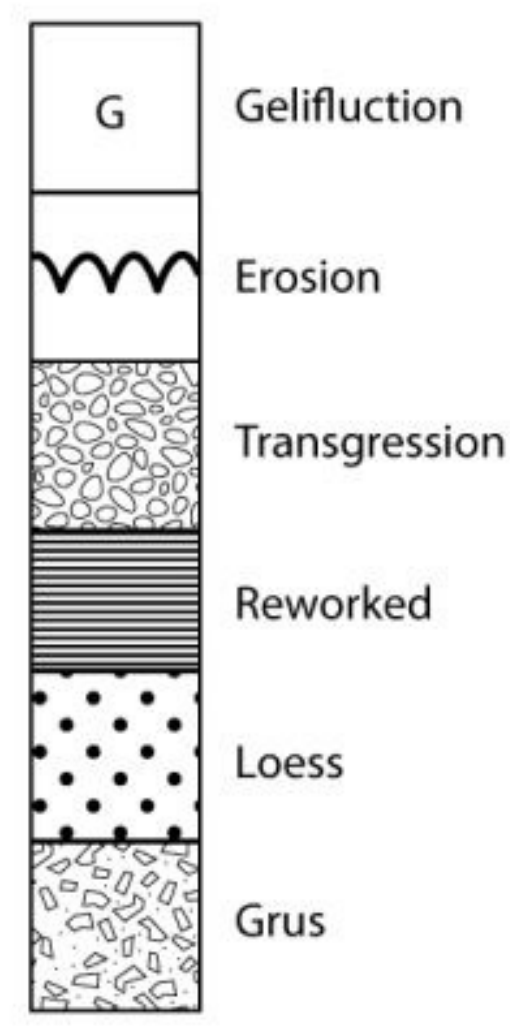

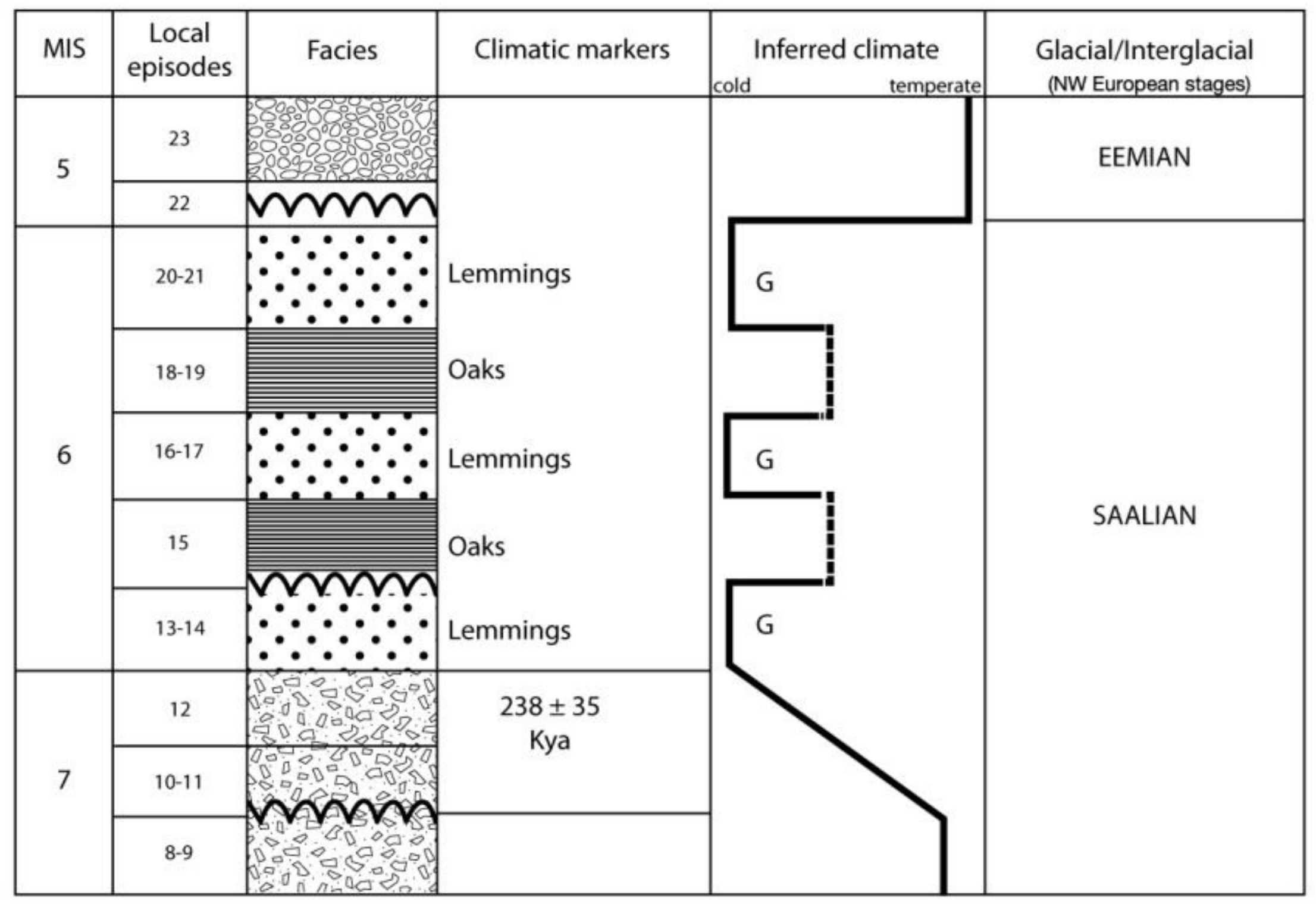




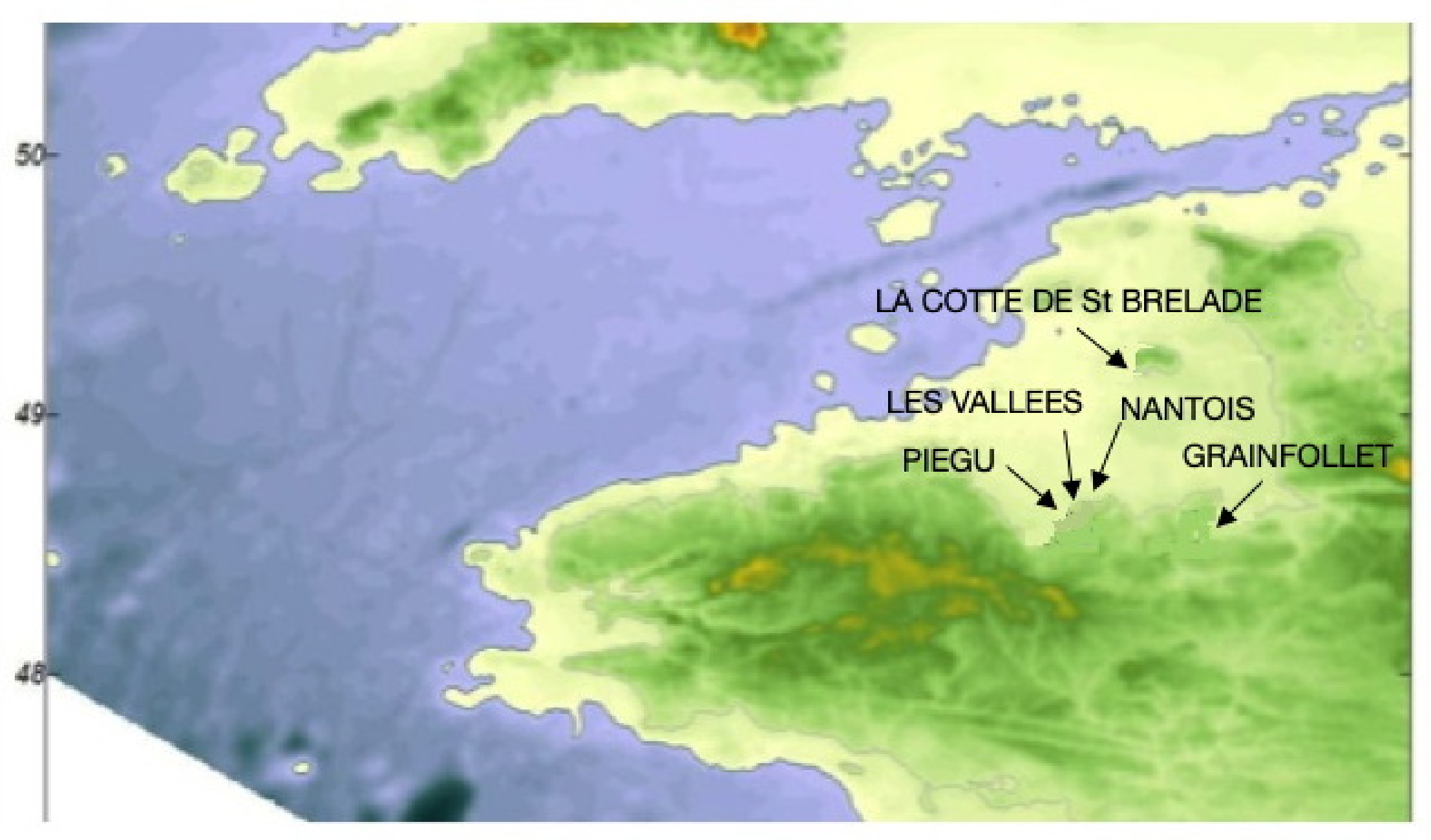




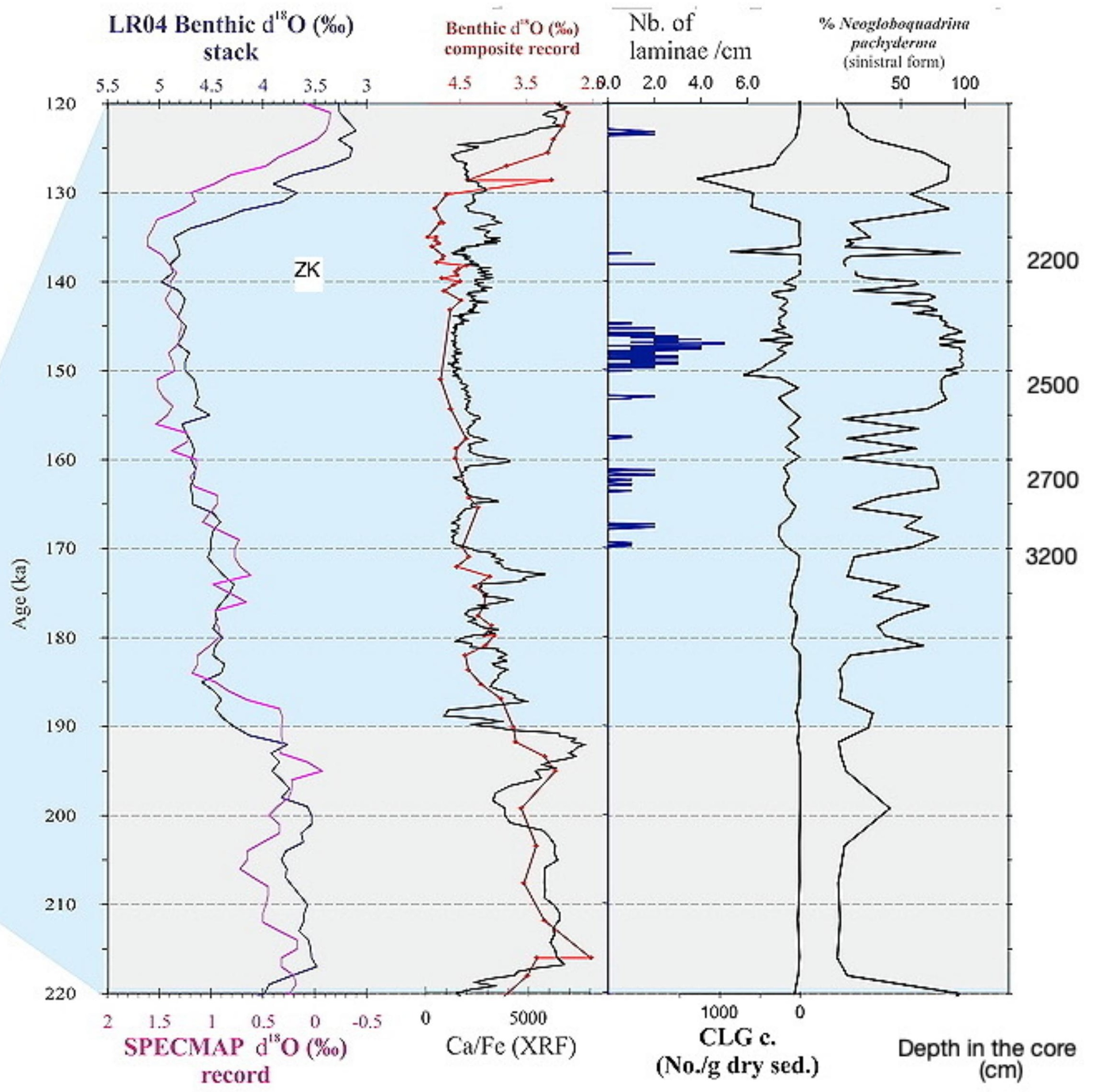


Offshore production of $\mathrm{Np}$
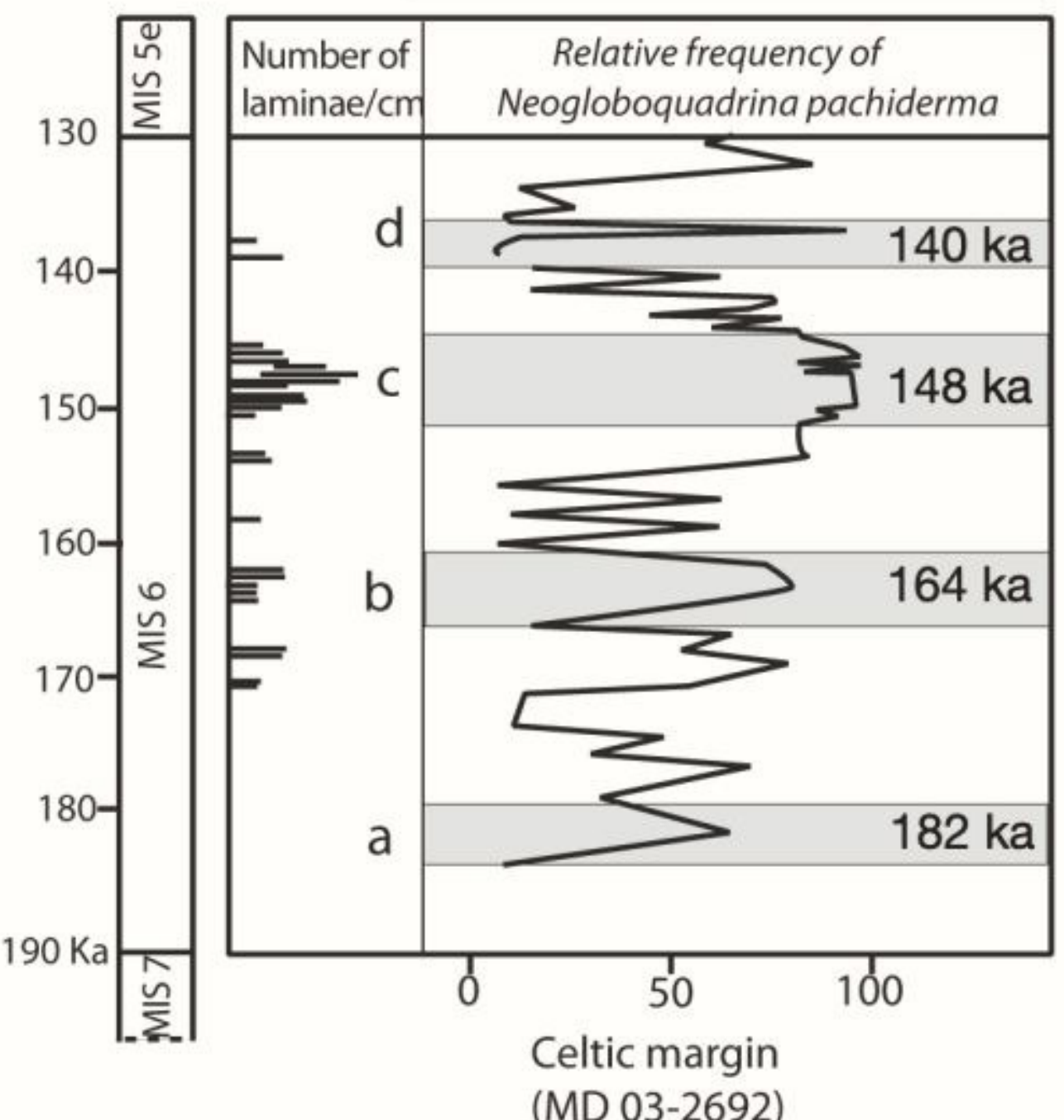

(MD 03-2692)

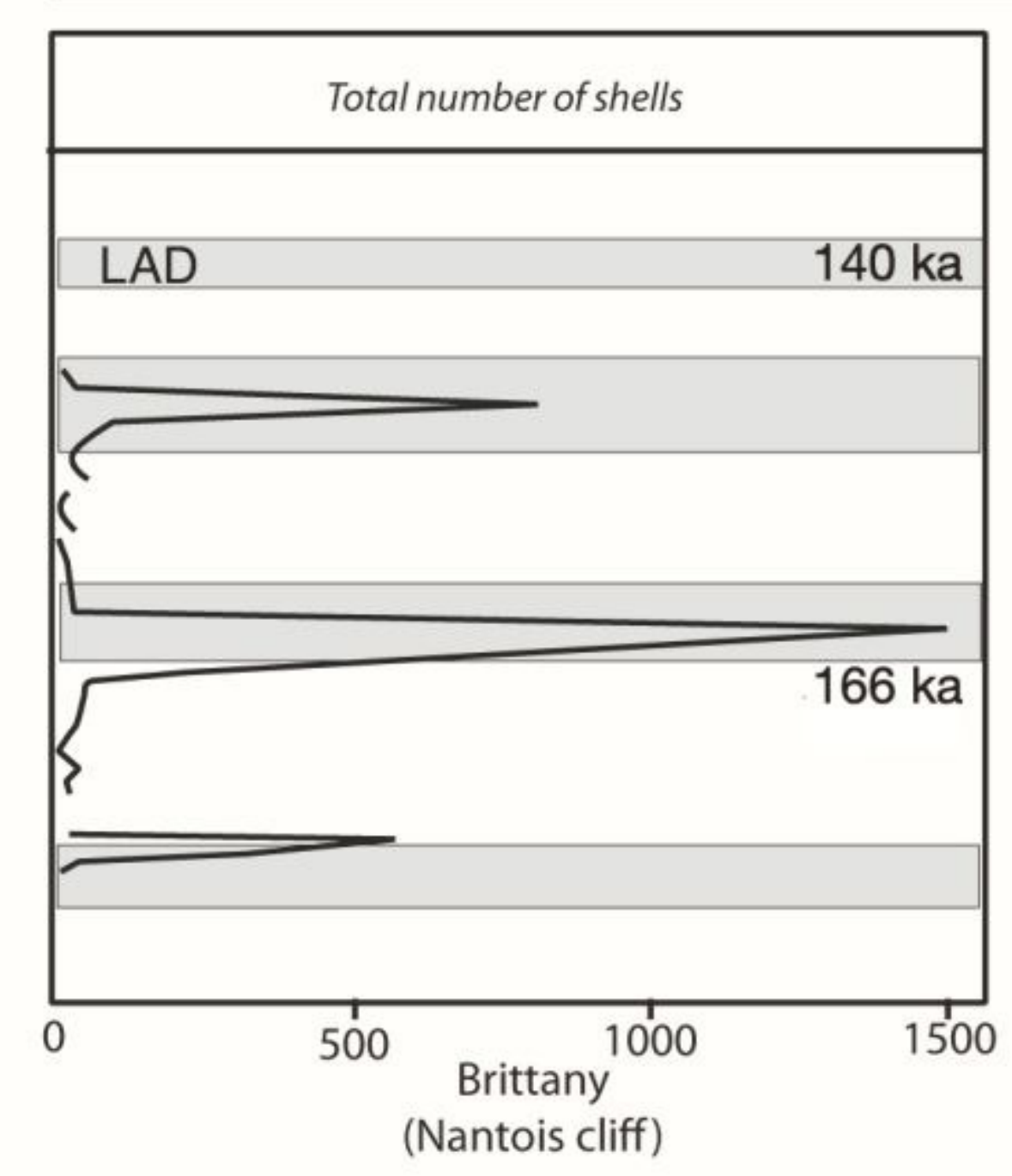

\section{Total onshore production of shells in loess}

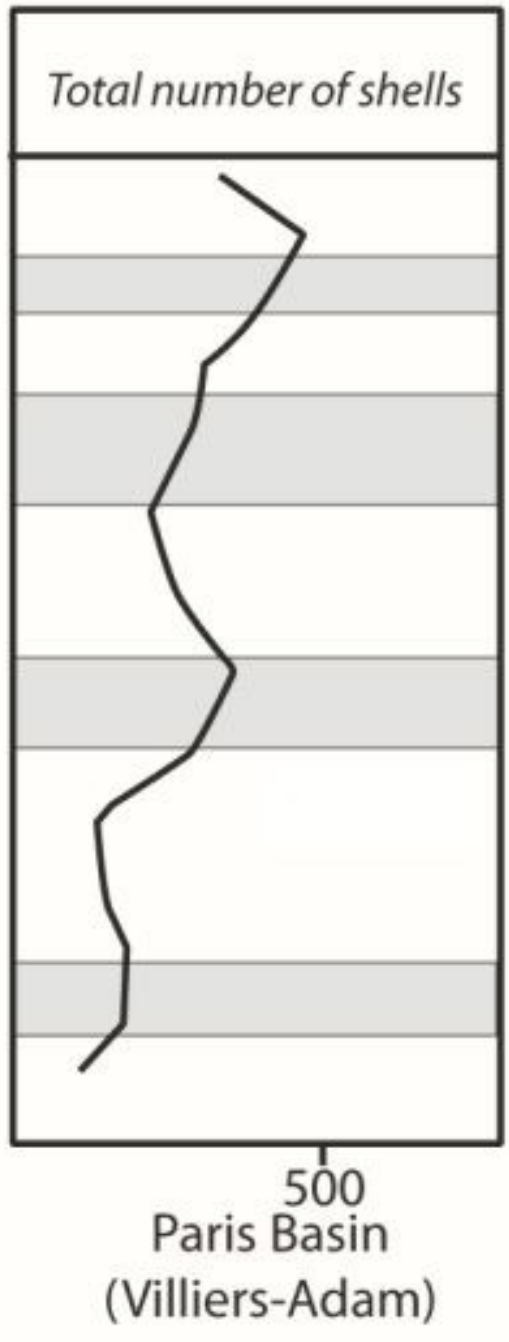



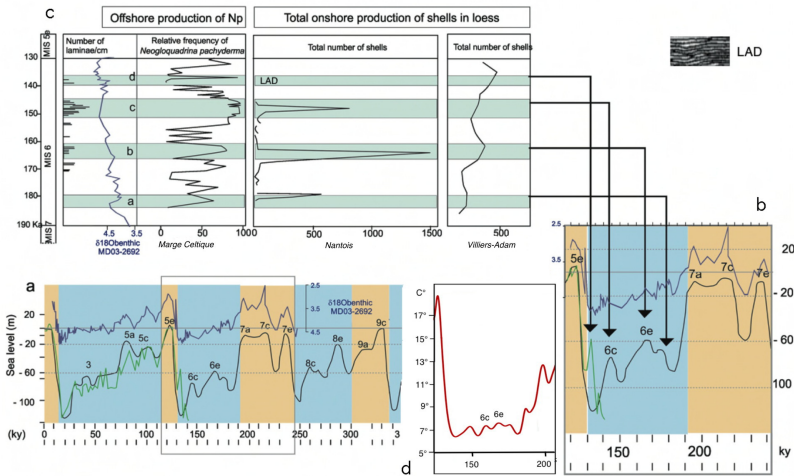


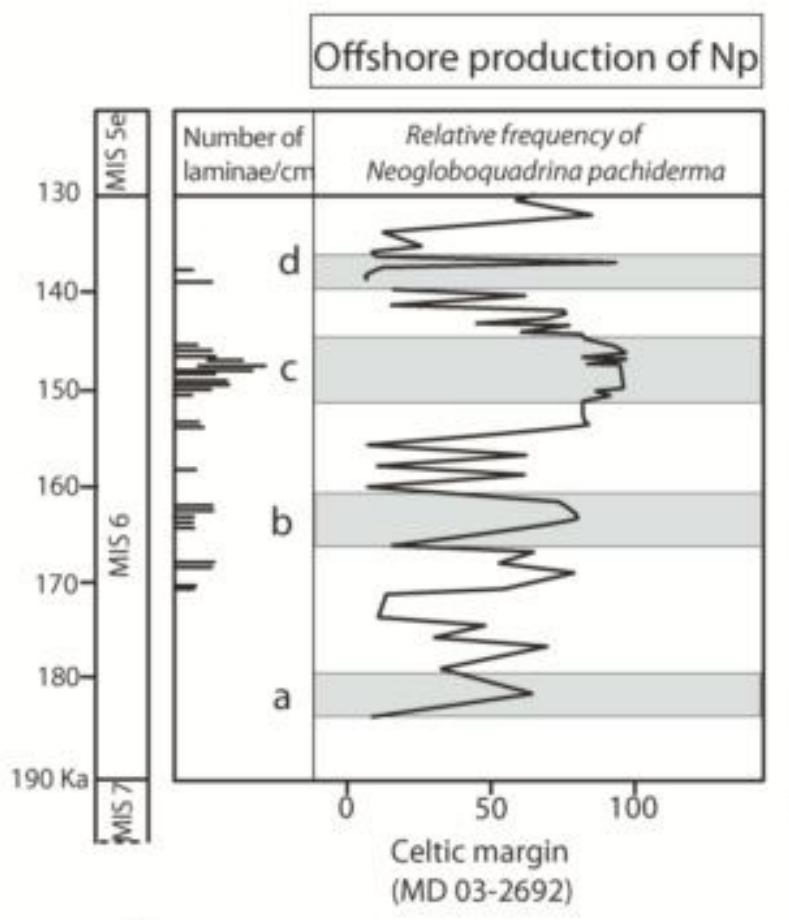

A
Total onshore production of shells in loess

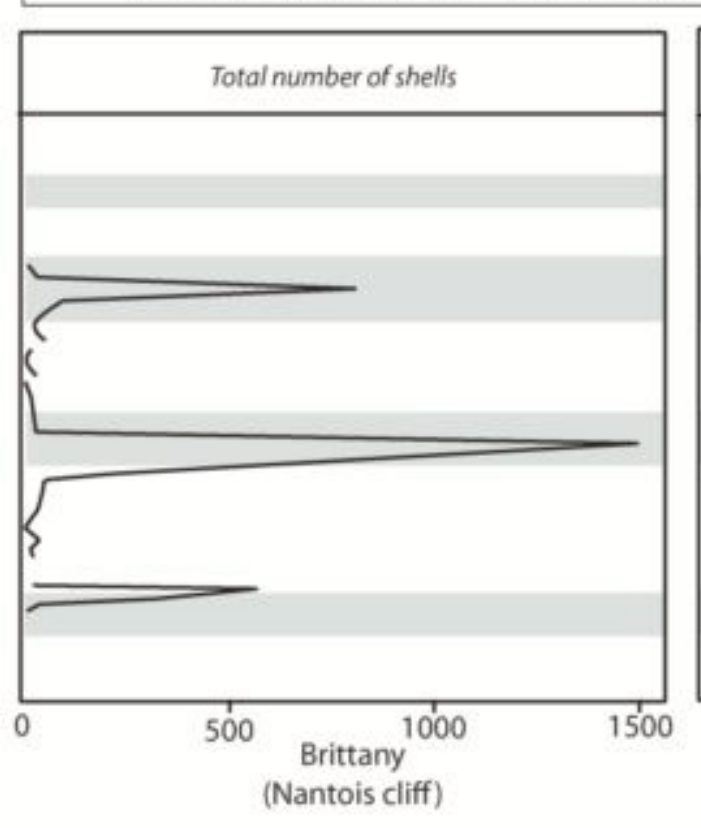

375

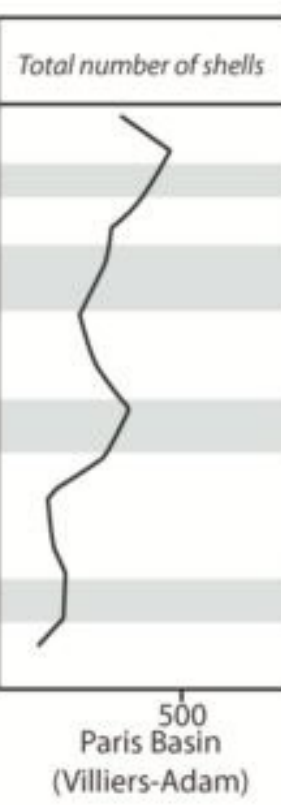
(Villiers-Adam)
$475 \quad 525$

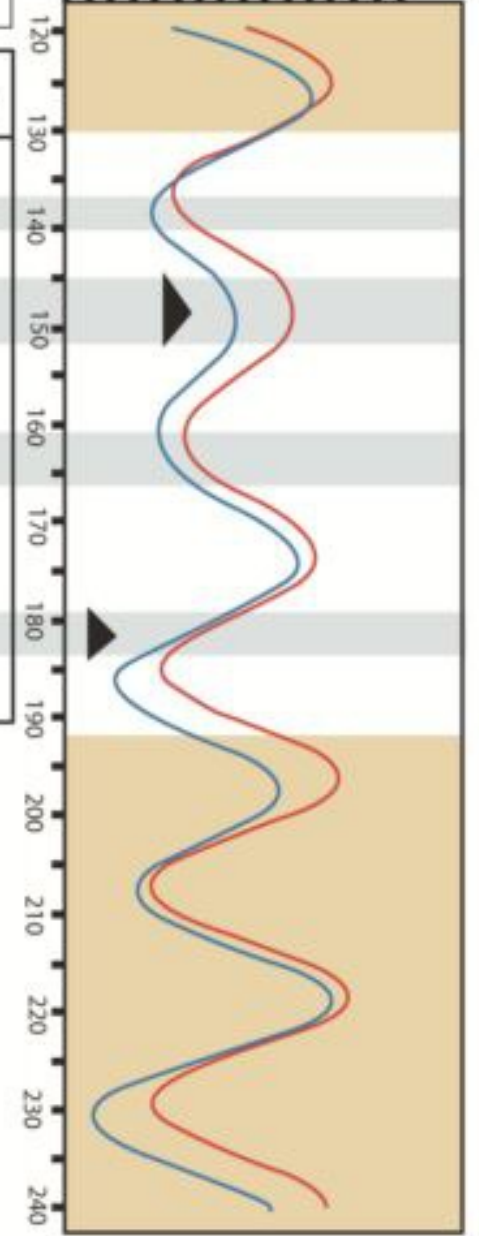

B

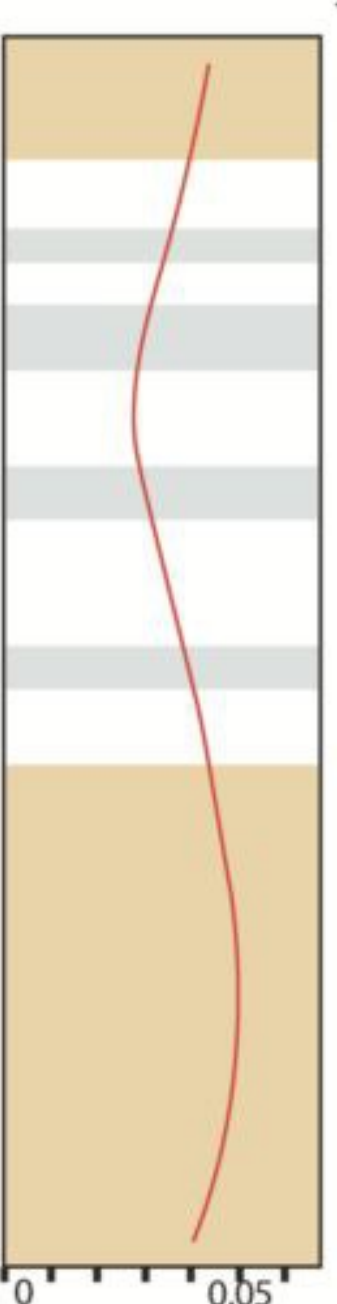

Eccentricity
$0.075-0.0250 .0250 .075$

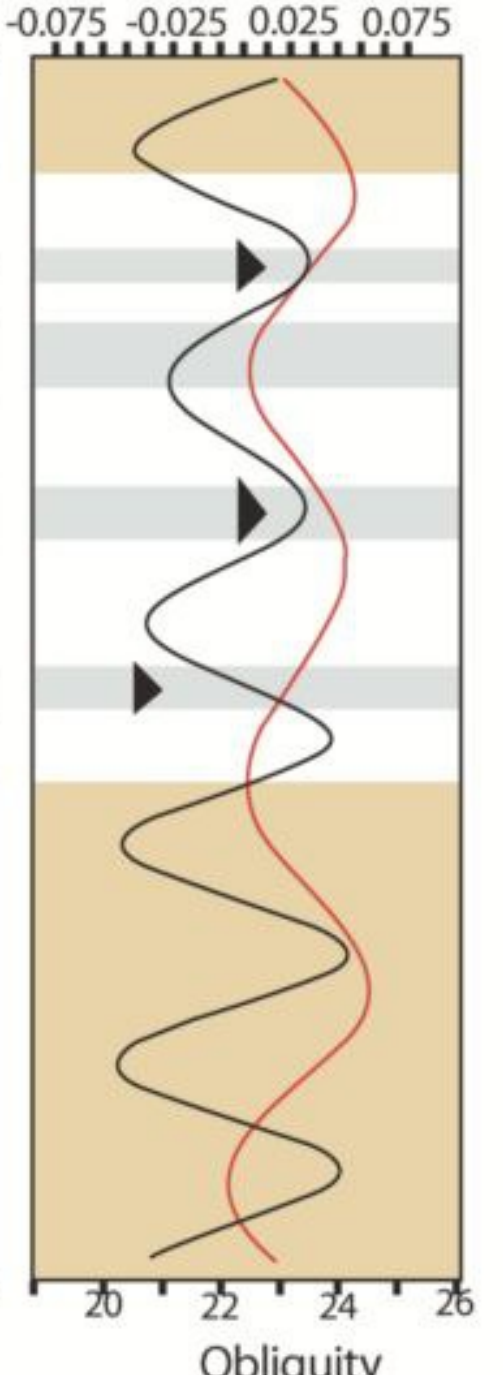



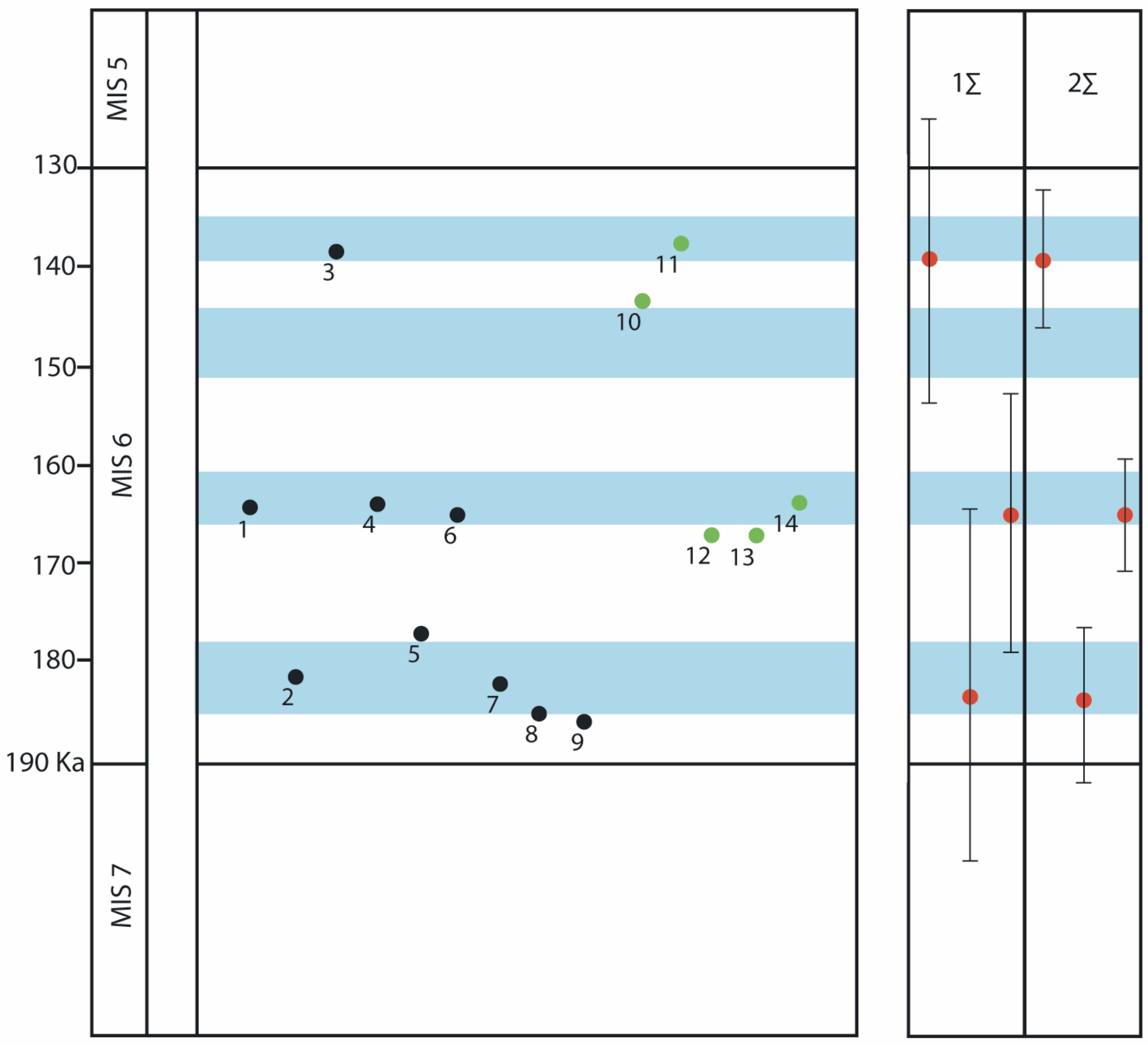

- Nantois and Piegu sites

- Grainfollet site 
Table 1.

\begin{tabular}{|c|c|c|c|c|c|c|c|c|c|c|c|c|c|c|}
\hline 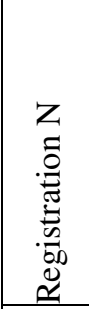 & $\begin{array}{l}\mathrm{Z} \\
\stackrel{\overline{0}}{\vec{J}} \\
\stackrel{\vec{J}}{ \pm}\end{array}$ & 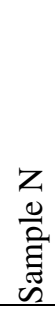 & 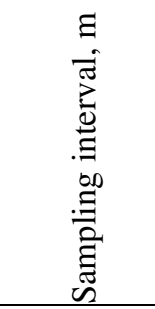 & 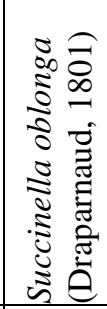 & 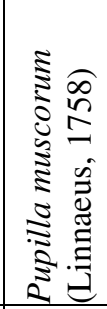 & 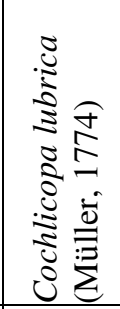 & 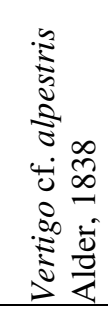 & 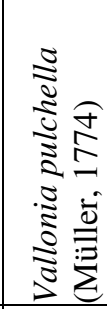 & 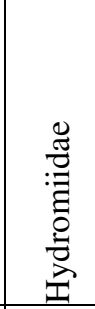 & 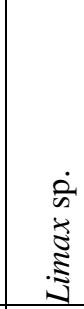 & $\begin{array}{l}\stackrel{n}{E} \\
\stackrel{\Xi}{0} \\
\frac{0}{0} \\
\overline{\bar{D}} \\
\bar{n}\end{array}$ & 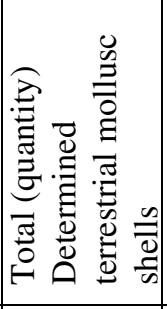 & 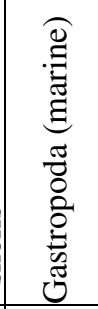 & 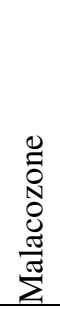 \\
\hline 3728 & \multirow{3}{*}{2} & 1 & $0-0,10$ & - & 46 & - & - & - & - & 2 & 1 & 48 & - & \multirow[t]{10}{*}{1} \\
\hline 3729 & & 2 & $0,10-0,20$ & - & - & - & - & - & - & - & 8 & 0 & - & \\
\hline 3730 & & 3 & $0,20-0,30$ & - & 1 & - & - & - & - & - & 168 & 1 & 16 & \\
\hline 3731 & \multirow{2}{*}{3} & 4 & $0,30-0,40$ & - & - & - & - & - & - & - & 65 & 0 & - & \\
\hline 3732 & & 5 & $0,40-0,50$ & - & 1 & - & - & - & - & - & 130 & 1 & 3 & \\
\hline 3733 & \multirow{10}{*}{4} & 6 & $0,50-0,60$ & - & 5 & - & - & - & - & - & 29 & 5 & 3 juv. & \\
\hline 3734 & & 7 & $0,60-0,70$ & - & 1 & - & - & - & - & - & 46 & 1 & 1 & \\
\hline 3735 & & 8 & $0,70-0,80$ & - & 4 & - & - & - & - & - & 28 & 4 & 5 & \\
\hline 3736 & & 9 & $0,80-0,90$ & - & 5 & - & - & - & - & - & 29 & 5 & 2 & \\
\hline 3737 & & 10 & $0,90-1,00$ & - & 5 & - & - & - & - & - & + & 5 & - & \\
\hline 3738 & & 11 & $1,00-1,10$ & - & 9 & - & - & - & - & - & 13 & 9 & 1 & \multirow[t]{4}{*}{2} \\
\hline 3739 & & 12 & $1,10-1,20$ & - & 53 & 1 & - & - & - & - & 42 & 54 & 2 & \\
\hline 3740 & & 13 & $1,20-1,30$ & - & 148 & - & 1 & - & - & 1 & 12 & 150 & - & \\
\hline 3741 & & 14 & $1,30-1,40$ & - & 2 & - & - & - & 1 juv. & - & 30 & 3 & - & \\
\hline 3742 & & 15 & $1,40-1,50$ & - & - & - & - & - & - & - & 228 & 0 & - & \multirow[t]{10}{*}{3} \\
\hline 3743 & \multirow{7}{*}{5} & 16 & $1,50-1,60$ & - & - & - & - & - & - & - & 82 & 0 & - & \\
\hline 3744 & & 17 & $1,60-1,70$ & - & - & - & - & - & - & - & 102 & 0 & - & \\
\hline 3745 & & 18 & $1,70-1,80$ & - & 1 & - & - & - & - & - & 246 & 1 & 3 & \\
\hline 3746 & & 19 & $1,80-1,90$ & - & - & - & - & - & - & - & 39 & 0 & - & \\
\hline 3747 & & 20 & $1,90-2,00$ & - & 3 & - & - & - & - & - & 86 & 3 & - & \\
\hline 3748 & & 21 & $2,00-2,10$ & - & 1 & - & - & - & - & - & 39 & 1 & - & \\
\hline 3749 & & 22 & $2,10-2,20$ & - & 2 & - & - & - & - & - & 6 & 2 & - & \\
\hline 3750 & \multirow{2}{*}{6} & 23 & $2,20-2,30$ & - & - & - & - & - & - & - & 10 & 0 & - & \\
\hline 3751 & & 24 & $2,30-2,40$ & - & - & - & - & - & - & - & 7 & 0 & 1 & \\
\hline 3752 & \multirow{2}{*}{7} & 25 & $2,40-2,50$ & - & 3 & - & - & - & - & - & 53 & 3 & 1 & \multirow[t]{5}{*}{4} \\
\hline 3753 & & 26 & $2,50-2,60$ & - & 1 & - & - & - & 1 juv. & - & 5 & 2 & - & \\
\hline 3754 & \multirow{3}{*}{8} & 27 & $2,60-2,70$ & - & 2 & - & - & 1 & - & - & 2 & 3 & - & \\
\hline 3755 & & 28 & $2,70-2,80$ & - & 7 & - & - & - & 2 juv. & - & 80 & 9 & 6 & \\
\hline 3756 & & 29 & $2,80-2,90$ & - & 55 & - & - & 6 & 19 & 1 & 390 & 81 & - & \\
\hline 3757 & \multirow{9}{*}{9} & 30 & $2,90-3,00$ & 1 & 5 & - & - & - & - & - & 48 & 6 & - & \multirow[t]{20}{*}{5} \\
\hline & & 31 & $3,00-3,10$ & - & - & - & - & - & - & - & - & - & - & \\
\hline 3758 & & 32 & $3,10-3,20$ & - & - & - & - & - & - & - & 2 & 0 & - & \\
\hline & & 33 & $3,20-3,30$ & - & - & - & - & - & - & - & - & - & - & \\
\hline & & 34 & $3,30-3,40$ & - & - & - & - & - & - & - & - & - & - & \\
\hline & & 35 & $3,40-3,50$ & - & - & - & - & - & - & - & - & - & - & \\
\hline \begin{tabular}{|l|}
3759 \\
\end{tabular} & & 36 & $3,50-3,60$ & - & - & - & - & - & - & - & 2 & 0 & - & \\
\hline & & 37 & $3,60-3,70$ & - & - & - & - & - & - & - & - & - & - & \\
\hline & & 38 & $3,70-3,80$ & - & - & - & - & - & - & - & - & - & - & \\
\hline & \multirow{11}{*}{10} & 39 & $3,80-3,90$ & - & - & - & - & - & - & - & - & - & - & \\
\hline & & 40 & $3,90-4,00$ & - & - & - & - & - & - & - & - & - & - & \\
\hline & & 41 & $4,00-4,10$ & - & - & - & - & - & - & - & - & - & - & \\
\hline & & 42 & $4,10-4,20$ & - & - & - & - & - & - & - & - & - & - & \\
\hline & & 43 & $4,20-4,30$ & - & - & - & - & - & - & - & - & - & - & \\
\hline & & 44 & $4,30-4,40$ & - & - & - & - & - & - & - & - & - & - & \\
\hline & & 45 & $4,40-4,50$ & - & - & - & - & - & - & - & - & - & - & \\
\hline & & 46 & $4,50-4,60$ & - & - & - & - & - & - & - & - & - & - & \\
\hline & & 47 & $4,60-4,70$ & - & - & - & - & - & - & - & - & - & - & \\
\hline & & 48 & $4,70-4,80$ & - & - & - & - & - & - & - & - & - & - & \\
\hline & & 49 & $4,80-4,90$ & - & - & - & - & - & - & - & - & - & - & \\
\hline & & & Total & 1 & 360 & 1 & 1 & 7 & 23 & 4 & 2038 & 397 & 44 & \\
\hline
\end{tabular}

Legend: + - shell fragments (size less than $1 \mathrm{~mm}$ ); juv. - juvenile mollusc shell 